\title{
|| Açık Havada Eğitim: Okul Öncesi Eğitim Programı Materyalleri Bağlamında Bir Değerlendirme*
}

\author{
Neşe AŞKAR ${ }^{1,2}$
}

\begin{abstract}
Öz: Araştırmanın amacı, Okul Öncesi Eğitim Programı'nın materyallerini oluşturan Bütünleştirilmiş Aile Destek Eğitim Rehberi (OBADER), Etkinlik Kitabı (2013) ve Öğretmenler İçin Etkinlik Kitabı'ndaki (2018) açık hava etkinliklerinin etkinlik çeşidi, gelişim alanı, konusu, ele aldığı kavramlar, açık havanın etkinlikte konumlanma biçimi gibi değişkenler açısından sistematik olarak incelenmesidir. Çalışmada doküman incelemesi tekniği kullanılmıştır. Elde edilen veriler, içerik analizi yöntemiyle analiz edilmiştir. OBADER'deki 62 etkinlikten bir tanesinin (\%1,6), Etkinlik Kitabı'ndaki 40 etkinlikten beş tanesinin (\%12,5), Öğretmenler İçin Etkinlik Kitabı'ndaki 340 etkinlikten 27 tanesinin $(\% 7,9)$ açık hava etkinliği olduğu belirlenmiştir. Etkinlik kitaplarında açık havada eğitime yer verme düzeyinin bu derece düşük olması gerek alanyazında gerekse programda vurgulanan önemin uygulamaya yansıtılamadığı şeklinde yorumlanabilir. Öncelikli eylem planı dâhilinde, eğitimcilere yön verme ve bu süreçte tutum geliştirme amacıyla, okul öncesi eğitim programının ve uygulamaya dönük materyallerinin daha çok sayıda ve çeşitlilikte açık hava etkinliğiyle zenginleştirilmesi yerinde bir uygulama olacaktır.
\end{abstract}

Anahtar Sözcükler: Okul Öncesi Eğitim Programı, Açık Hava Etkinliği, Etkinlik Kitabı

\section{Outdoor Education: An Evaluation in the Context of Preschool Education Program Materials}

\begin{abstract}
The aim of the study is to determine the type of activity, area of development, subject, concepts and the manner in which the outdoors are positioned in the Integrated Family Support Education Guide (OBADER), the Activity Book (2013) and the Activity Book for Teachers (2018), which are the materials of the Preschool Education Program. A document review technique was used in the study, and the data were analyzed through the content analysis method. One of the 62 activities in OBADER (1.6\%), five of the 40 activities in the Activity Book (12.5\%) and 27 of the 340 activities in the Activity Book for Teachers $(7.9 \%)$ were found to be outdoor activities. The fact that the Activity Books give a limited attention to outdoor activities is considered to show that the program does not emphasize teaching outdoors. Within the priority action plan, it will be appropriate to enrich the preschool education program and the practical materials with a greater number and variety of outdoor activities with the aim of guiding educators and developing attitudes in this process.
\end{abstract}

Keywords: Preschool Education Program, Outdoor Activity, Activity Book

* Bu çalışma 19-22 Haziran 2019 tarihleri arasında Ankara'da düzenlenen VI. International Eurasian Educational Research Congress'de sözlü bildiri olarak sunulmuştur.

${ }^{1}$ Milli Eğitim Bakanlığı, Ankara, Türkiye, e-mail: askarnese@gmail.com, ORCID: https://orcid.org/0000-0002-2305-9481

2 Hacettepe Üniversitesi, Eğitim Fakültesi, Temel Eğitim Bölümü, Ankara, Türkiye
} 
Artan şehirleşmeyle azalan doğal yaşam alanları, kirlilik oranlarının yüksek oluşu, trafik yoğunluğu, anne-babaların çalışma saatlerinin fazlalığı, kurum bakımına tabi olan çocuk sayısındaki artışlar ve güvenlik kaygıları gibi sebepler çocukların açık havaya erişimini azaltmıştır. Okul için ayrılan sürenin uzunluğu ve planlı etkinliklerin yoğunluğu (spor, ders, etüt, ilave sanatsal aktiviteler vs.) da çocukların açık havadan yeterince faydalanamamasının diğer nedenleri arasında sayılabilir. Tüm bunlara klimalı oyun alanları, televizyon, bilgisayar ve elektronik oyun(cak)lar da eklenince her geçen gün daha fazla sayıda çocuk kapalı mekânlarda yaşamak zorunda kalmaktadır (Clements, 2004; Herrington ve Studtmann, 1998; Rivkin, 1998; Tucker, 2008; Valentine ve McKendrick, 1997). Artık çocuklar için eğlenmenin, hoşça vakit geçirmenin anlamı; televizyon seyretmek, bilgisayar, tablet, akıllı telefon gibi dijital araçlarla baş başa kalmak ya da alışveriş merkezleri bünyesinde yer alan gürültü ve 1şık kirliliğinin yoğun olduğu alanlarda bulunmak / oynamak olmuştur (Alat, Akgümüş ve Cavalı, 2012; Burdette ve Whitaker, 2005a). Çevresel koşullar ve kent şartları da bu durumu sürekli hale getirmektedir.

Doğum oranlarının her geçen yıl daha da azalması ve aile başına bir ya da iki çocuğun düşmesi ile çocuğa verilen önem ve değer artmıştır (Sunar ve Fişek, 2005). Bu yüklemeler, korumacı anne baba tutumlarında artışa yol açarak ebeveynleri, riskten kaçınan, kendi yaşadığı sokaktan korkan, dijital medya bağımlısı, obezite ve diğer bazı sağlık sorunları ile erken yaşta yüzleşmiş izole çocukların yaratıcısı haline dönüştürmüştür (Burdette ve Whitaker, 2005a). Bu gelişmelerin bir sonucu olarak, okul öncesi eğitim alan az sayıdaki çocuk da sınırlı fiziksel ve açık alan koşullarına sahip olan binalarda eğitim almak zorunda kalmaktadır (Hearron ve Hildebrant, 2013; Kelley ve Williams, 2013; Talay, Aslan ve Belkayalı, 2010). Görüldüğü üzere, bugün dünyanın hemen her yerinde, çocukların dış mekân oyunlarına erişimi, değişen yaşam biçimleri nedeniyle sürekli olarak aşınmaktadır.

Bireylerin doğayla kurdukları bağ, çevreye yönelik tutumları ile ilişkilidir. Birey kendisini doğanın bir parçası olarak görürse, çevreye yönelik olumlu tutumlar geliştirmektedir (Schultz, Shriver, Tabanico ve Khazian, 2004). Bu bağın kurulabilmesi içinse doğada ve açık alanlarda vakit geçirmek gerekli (Herrington ve Studtmann, 1998; White, 2004) olmakla birlikte, geçirilen zamanın özellikle erken çocukluk döneminde olması kritiktir (Waite, 2010). Bugün ise doğadan zevk alma ve yararlanma kapasitesi, kayıtsızlığa ve korkuya evrilmiştir (Altman ve Wohlwill, 1978). Louv'un (2010) da ifade ettiği gibi "Yeni kuşak için doğa bir gerçeklikten çok bir soyutlamadır. Doğa, gün geçtikçe, seyredilecek, tüketilecek, giyinilecek, hatta görmezden gelinecek bir şeye dönüşüyor.". Bazı araştırmalarda da kentsel alanlarda büyüyen çocukların, doğaya özgü varlık ya da nesnelere ilişkin temelsiz korku ve iğrenme duyguları geliştirme eğiliminde oldukları görülmektedir (Bixler, Carlisle, Hammltt ve Floyd, 1994; Wilson, 2008). Özetlemek gerekirse, çocuklar her geçen gün doğaya yabancılaşmaktadır.

Eğitim dünyasında çocuğun değişen doğasına yönelik bu farkındalık ve kaygı, açık havada geçirilen zamana yönelik ilginin artmasıyla sonuçlanmıştır (Staempfli, 2009). Yaşanan bu ilgi artışıyla birlikte özellikle okul öncesi dönem çocuğunun gelişimine sunulabilecek katkılar belirgin hale gelmiştir. Okul öncesi eğitim kurumlarının, açık hava etkinliklerine düzenli ve yeterli zamanı ayırması, çocuklara doğayla etkileşim olanakları sunması hem çocukların sağlıklı yetişmelerini hem de doğayı seven ve korumaya çabalayan bireyler olarak yetişmelerini sağlamak açısından oldukça önemlidir (Alat ve diğerleri, 2012). Bu önem, artan farkındalığı da beraberinde getirmektedir.

\section{Açık Havada Geçirilen Zamanın Çocuğun Gelişimi ve Öğrenmesi Açısından Önemi}

Küçük çocuklar çevre ile etkileşime girerek öğrendikleri için eğitimciler ve diğer yetişkinlerin ilk yıllarda çocuk-çevre etkileşimlerinin sıklığına, doğasına ve kalitesine katkı sunmaları gerekir. Her yaşta olduğu gibi erken çocukluk döneminde de açık alanda geçirilen zaman, çocuğun fiziksel sağlığı açısından da oldukça önemlidir. Hearron ve Hildebrand (2013) ile Bilton'ın (2010) da ifade ettiği gibi, temiz hava, güneş ışığı ve hareket, iyi planlanmış açık hava oyunlarının sağladığı başlıca yararlardandır. Doğa, güneş ışığı aracılığıyla D vitamininin kaynağıdır. Açık havada yürütülen faaliyetler, ince motor gelişimini ve göz-el-ayak koordinasyonunun gelişimini arttırır. Örneğin, doğal alanlarda oynayan çocukların motor sporlarında daha iyi koordinasyon, denge ve çeviklik sergileme düzeylerinde istatistiksel olarak manidar iyileşmeler elde 
edildiği belirlenmiştir (Fjortoft, 2001, 2004; Fjortoft ve Sageie, 2000). Bu tür aktiviteler bu yaştaki çocuklar için son derece önemlidir, çünkü motor beceri gelişimi okul öncesi çocukların birincil ve kritik gelişimsel görevlerinden biridir (Davies, 1996; Essa, 1992). National Association for Sport and Physical Education'da (NASPE) (2005) ifade edildiği gibi, erken çocukluk döneminden itibaren, çocukların günde en az 60 dakika açık havada serbest zaman geçirmelerinin sağlanması ve buna ek olarak hareketsiz kaldıkları zamanın bir saati aşmaması, koruyucu tedavi olarak önerilmektedir. Erken çocukluk döneminde temel motor becerilerin gelişimi, sadece çocukların kolay ve işlevsel bir şekilde hareket etmeleri için değil, aynı zamanda hareketteki yetkinliğin çocukların sosyal ve duygusal gelişimleriyle de ilgili olması nedeniyle önemlidir (Poest, Williams, Witt ve Atwood, 1990, akt. Davies, 1996; Fjortoft, 2004). Görüldüğü üzere, açı havada eğitim çocuğun bütünsel gelişimini destekleyen zengin bir ortamdır.

Açık havanın sunduğu zengin gelişim ortamının sağladığı gelişim olanakları açıtır. Dış ortamın sınırlı kullanımı, çocukların büyük kas becerilerini geliştirme yeteneklerini de kısıtlamaktadır (Towell, 2005). Motor becerileri hakkında kendinden şüphe duymak, çocuğun öğrenme ve öz yeterlik kapasitesini etkiler. Keşfetmekte, gözlemlemekte ve taklit etmekte özgür olan çocuklar güven geliştirir. Öz yeterlik algıları yüksek olan çocuklar zorluklarla mücadele eder ve başarılı oluncaya kadar farklı stratejiler dener. Öz yeterlik algısı düşük olan çocuklar ise, yeteneklerinden şüphe eder ve denemekten çabuk vazgeçme eğilimi sergilerler. Yetişkinler, aşırı temkinli ve koruyucu davranarak çocukların öz yeterlik algılarının gelişimine de ket vururlar ve keşif fırsatlarını sınırlandırırlar (Hearron ve Hildebrand, 2013). Özetle, çocukların açık havada edindikleri deneyimler yoluyla geliştirdikleri güven ve yeterlik duygusu, yaşamın tüm alanlarını etkileme potansiyeline sahiptir. Hayatlarının geri kalan kısmında meraklı, keşfeden, yılmazlık düzeyi yüksek, zorluklara göğüs geren, çabanın önemine inanan güçlü bireyler olmalarının ya da tam tersi bireylere dönüşmelerinin temelleri, aslında bu dönemlerde atılmaktadır.

Açık hava etkinlikleri, çocukların aktif katılımcılar olarak yaparak-yaşayarak öğrenmelerine fırsatlar sunar. Erken çocukluk döneminde çocuklar, duyularını kullanarak öğrenir ve duyusal öğrenme yoluyla edindiklerini uzun süreli hafızalarına kaydederler (Khan, 2012). Louv'un (2010) da ifade ettiği gibi, duyusal deneyimler çocuğun dış dünyası ile duygu dünyası arasında bağ kurar. Çocuğun duygu dünyasının ve içsel farkındalığının sağlıklı gelişimi için, duyusal uyaranların temel kaynağı olan doğal çevrede, duyularını kullanarak çevresini keşfetmesi özel bir öneme sahiptir. Çocuklar açık havada geçirdikleri zaman sayesinde merak duygularını harekete geçirerek dünyayı ilk elden keşfedip çıkarım, ölçme ve gözlem yapma gibi bilimsel araştırma süreciyle ilgili becerilerini de kullanarak hava, değişen mevsimler ve gölgeler gibi doğal olguları deneyimlerler (Bilton, 2010; Civelek ve Akamca, 2017). Açık havada eğitimin okul öncesi ve ilkokul çocuklarının okuryazarlık becerilerinde ve entelektüel gelişimlerinde de etkili olduğu belirlenmişlerdir (Cooper, 2015; Hearron ve Hildebrant, 2013; Kellert, 2005; Quigley, Pongsanon ve Akerson, 2011). Daha açık bir ifadeyle, doğal ortamlara yakınlık ve sık erişim, çocukların bilişsel yeteneklere odaklanma ve güçlendirme kapasitelerini artırmaktadır (Wells, 2000). Bu da elbette ki akademik ilerleyiş ve başarıyı beraberinde getirmektedir.

Açık havanın sunduğu olanaklar motor, bilişsel, duygusal gelişimin de ötesindedir. Açık hava etkinliklerine katılmak çocukları sosyal olarak da destekler. Araştırmalardan elde edilen sonuçlar, açık hava ortamlarının çocukların yaratıcı oyunlarını, akranlarıyla ilişkilerini ve çevreyle ilişkilerini olumlu şekilde etkilediğini ortaya koymaktadır (Dowdell, Gray ve Malone, 2011). Akranları ile oyun oynamak çocuklara kendi öğrenmelerini yönlendirme konusunda deneyim sağlar (Perry, 2001). İç mekânlara göre açık alanların daha büyük oluşu, gürültünün engellenmesine çaba gösterilmemesi, çocuklarda özgürlük hissi uyandırır (Davies, 1996; Hearron ve Hildebrand, 2013). Daha da önemlisi açık havada geçirilen zamanın psikolojik iyi oluş, duyusal farkındalık, dinginleşme açısından sunduğu olanaklardır (Davies, 1996; Louv, 2010). E. Wilson'un (2003) Biophilia Hipotezi, insan türünün doğadaki diğer yaşam formlarılya ilişki kurma ve bağlantı kurma konusundaki köklü ihtiyacını dile getirir. Bu ihtiyaç sağlanmadığında, Louv'un (2010) tanımlaması ile "doğa yoksunluğu sendromu" ortaya çıkar ki bu da doğaya yabancılaşmanın insan üzerindeki olumsuz etkisini vurgulayan bir durumdur. Bu etkiler arasında, duyuların daha az kullanılması, dikkat sorunları ve fiziksel-ruhsal hastalıklar, artan suç oranları gibi problematik durumlar yer alır. Bu sendrom 
bireylerde, ailelerde ve topluluklarda görülebilir. Çözümü ise doğanın sağaltıcı etkisidir. Benzer şekilde Woolley ve Lowe (2013) da çocuk için doğal bir çevrede oynamanın, güven, bağımsızlık, koordinasyon, denge ve çeviklik gibi motor becerilerde artışa neden olabileceğini, stresin etkilerini azaltıp Dikkat Eksikliği Hiperaktivite Bozukluğu (DEHB) belirtilerini azaltabileceğini belirtmektedirler.

Sonuç olarak açık havada geçirilen zamanlar, çocuğun bedensel ve ruhsal sağlığının yanı sıra çok yönlü gelişimine de katkı sağlar. Bu sebeple açı havada ve özellikle de doğada yürütülen aktiviteleri eğitim ortamlarından ayrı düşünmek oldukça kısıtlayıcıdır. Açık havada yürütülen aktiviteler eğitim ortamının bütünleyici bir parçası olmalıdır.

\section{Eğitim Programlarında Açık Hava Aktivitelerine Yer Verilme Durumu}

Okul öncesi dönemde çocuğun gelişiminin bir bütün olarak düşünülmesi ve uygulanacak eğitim programlarına da bu bütünlüğün yansıtılması önemlidir. Açık hava etkinliklerinin çocukların gelişiminde birçok olumlu etkisine rağmen, okul öncesi eğitim programlarında açık hava etkinliklerine gereken önemin verilmemesi, hâlihazırdaki pasif yaşantının çok daha erken yaşlara çekilmesine neden olmaktadır (Alat ve diğerleri, 2012). İç ve dış mekân bu bütünlügüun bir yansısı olarak birlikte düşünülmelidir (Hart ve Sheehan, 1986). Uygulamaya dönük olarak sürecin yapılandırılmasında çocuğun katılımı, doğa dostu yaklaşım, disiplinler arası iş birliği-uyum ve çocuğun yüksek yararı gözetilerek bütünlük sağlanmalıdır (Talay ve diğerleri, 2010). Tüm bunların sağlanabilmesi adına, açık hava oyunlarının çocuğun potansiyelini gerçekleştirmesine olanak sağlaması için, yetişkinlerin destekleyici tutumları eşliğinde kaliteli ortam düzenlemesi ve planlaması gerekmektedir.

Okul öncesi öğretmenlerinin açık hava etkinliklerine yönelik görüş ve uygulamalarının araştırıldığı çalışmalarda, öğretmenlerin açı hava etkinliklerine yönelik genellikle olumlu tutumlara sahip oldukları, ancak dezavantajlı fiziki olanaklar, kalabalık sınıflar, destek eleman eksikliği / yetersizliği, dış mekânların oyunun doğasına uygun olmaması, hava koşullarının elvermeyişi ya da engelleyici veli tutumları gibi nedenlerle uygulamada yetersiz kaldıkları saptanmıştır (Çelik, 2012; Maynard ve Waters, 2007; Waite, 2010; Wilson, 2008). Alat ve diğerlerinin (2012) yürüttüğü araştırmada da açık hava etkinliklerinin öğretmenler tarafından eğitsel bir etkinlik olmaktan çok, güzel havaları bahçede geçirme, dışarıda oyun oynama etkinliği olarak algılandığı görülmüştür. İlkokullara bağlı okul öncesi sınıflarının kendilerine ait oyun alanlarının olmayışının da açık hava etkinliklerini sınırladığı belirlenmiştir. Shim, Herwig ve Shelley (2001) tarafından yapılan araştırmada, öğretmenlerin açık havada yürüttükleri etkinliklerde, ortam düzenlemesi, zenginleştirilmesi veya planlamasında sorunlar yaşadıkları ifade edilmiştir. Uygulamalardaki bu eksiklik ya da yanlışlıklar, başarı odaklı veliler ya da politika yapıcılardan kaynaklanan (sınava dayalı başarı sistemleri gibi) uygulamaların aşırı önemsenmesinden, öğretmenlerin açık hava etkinlikleri tasarlayabilme becerilerine ilişkin yeterliklerinin düşük olmasından, destek personel eksikliklerinden ya da açk hava etkinliklerinin değerinin anlaşılamamış olmasından kaynaklanabilir.

\section{Millî Eğitim Bakanlığı Okul Öncesi Eğitim Programı ve Etkinlik Kitapları}

Millî Eğitim Bakanlığı (MEB) Okul Öncesi Eğitim Programı (2013a), 36-72 aylık çocuklar için geliştirilmiş olup 2013 yılında okul öncesi eğitim alanındaki yenilikler ve geribildirimlere paralel olarak yeniden düzenlenmiştir. Bu düzenlemenin sonucunda, program kitabı ve etkinlik kitabı hazırlanmıştır. Okul öncesi dönem çocuklarının çok yönlü gelişimini amaçlayan programda, çocukların zengin öğrenme deneyimleri aracılı̆̆ıyla sağlıklı büyümeleri; motor, sosyal ve duygusal, dil ve bilişsel gelişim alanlarında gelişimlerinin en üst düzeye ulaşması, öz bakım becerilerini kazanmaları ve ilkokula hazır bulunmaları amaçlanmıştır. Bu amacı gerçekleştirmek için ilköğretimde kazandırılması hedeflenen ortak becerileri (problem çözme, akıl yürütme, yaratıcılık vb.) kapsayan bu program, çocuk merkezlidir. Program, çocukların bütün gelişim alanlarının geliştirilmesini esas alan gelişimsel bir programdır. Yaklaşım olarak sarmal özellik gösteren bu program, model olarak eklektiktir. Programda, kazanım ve göstergeler temel alınmıştır. Uygulamada bireyselleştirilmeye uygun yapısı sebebiyle esnek, tekrara olanak sağlamasıyla sarmal, etkinliklere ayrılan sürenin dengeli bir şekilde ayarlanması önemsediği için dengelidir. Program savunduğu ilkeler gereği keşfederek öğrenmeyi önemser ve yaratıcılığın gelişimi ön plandadır. Temalar/konular amaç değil araçtır. 
Öğrenme merkezleri, kültürel ve evrensel değerler, aile eğitimi ve katılımı, rehberlik hizmetleri önemlidir. Özel gereksinimli çocuklar için uyarlamalara yer vermektedir. Değerlendirme süreci çok yönlüdür. Programın temel öğeleri, 36-72 aylık çocukların gelişim özellikleri, amaç, kazanımlar, belirli gün-haftalar ve kavramlardır. Bu öğeler doğrultusunda uygulamaya yönelik, aylık planlar ve günlük akış, aile katılımı çalışmaları hazırlanır (MEB, 2013a). Program, okul öncesi dönemin öneminden bahsederken, çocuğa keşfetme olanağı sunan ve yaratıcılığı destekleyen çevre olanaklarına vurgu yapar. Çocukların özgür deneyimler yaşayarak rahat hareket edebildikleri ortamlarda daha iyi gelişip becerilerini sergileyebildiklerini ifade eder. $\mathrm{Bu}$ amaçla çocukların deneyimini zenginleştiren öğrenme merkezlerinin iç mekânlarda olduğu kadar dış mekânlarda da düzenlenmesi gerektiğini öngörür. Bu öngörü, Okul Öncesi Eğitim Programı'nın açık havada eğitime verdiği önemi göstermektedir. Örneğin "Etkinlik Çeşitleri ve Açıklamaları" başlığı altında "Öğretmen veya çocuklar tarafından yapılandırılmış, yarı yapılandırılmış ya da yapılandırılmamış etkinlikler sınıf içinde yapılabileceği gibi açık havada da yapılabilir." ifadesinde açık havada eğitime belirgin bir yönlendirme vardır. Başka bir bölümde, etkinliklerin yürütülmesine yönelik olarak “... öğretmenlerin bu etkinlikleri mümkün olduğunca açık havada da gerçekleştirmesi beklenmektedir" ifadesi yer almaktadır. Benzer bir vurgu da "Hareket Etkinliği" alt başlığı altında "Etkinliklerde top, ip, tebeşir, hullahup, denge tahtası gibi yapılandırılmış materyaller gibi açık hava oyun materyallerinin kullanımına ek olarak doğanın çocuklara sunduğu farklı yapıdaki zeminler, tırmanma olanakları, denge için kullanılabilecek kütükler gibi materyal ve ortamların kullanımı ön plana çıkartılmaktadır." ifadesinde dikkati çekmektedir.

$\mathrm{Bu}$ programla birlikte, öğretmenin hazırlayacağı etkinliklere örnek olması amacıyla farklı yaş gruplarındaki çocuklar için 40 etkinlikten oluşan Etkinlik Kitabı (MEB, 2013b) ve programla birlikte kullanılmak üzere Okul Öncesi Eğitimi Programı ile Bütünleştirilmiş Aile Destek Eğitim Rehberi (MEB, 2013c) ve ardından Öğretmenler için Etkinlik Kitabı (MEB, 2018) hazırlanmıştır.

Etkinlik Kitabı sunduğu sınırlı sayıda (40 adet) etkinlik örneği nedeniyle Temel Eğitim Genel Müdürlüğü tarafından 2018 yılında, etkinlik havuzu oluşturulmasının önemi ve gerekliliği, izleme ve değerlendirme sonuçları, okul yöneticileri ve okul öncesi öğretmenlerinin geri bildirimleri, yanlış uygulama örneklerinin yer aldığı hazır planların yaygınlaşmış olması gibi nedenlerden dolayı öğretmene sınıf içi uygulamalarında rehber olacağı düşünülen Öğretmenler için Etkinlik Kitabı hazırlanmıştır. Eğitim Bilişim Ağı'nda (EBA) da yayınlanan kitapta yer alan 340 etkinlikte, Okul Öncesi Eğitim Programının temel ilkeleri benimsenmiş ve programda yer alan tüm kazanım ve göstergelere, belirli gün ve haftalara yer verilmiştir (EBA, 2018). Başka bir deyişle kitap, programın uygulamaya dönük geniş çaplı ve güncel bir yansısıdır.

Öğretmenler için Etkinlik Kitabı'nın tanıtımında, içeriğindeki etkinliklerin örnek niteliğinde olup sınıf içinde uygulanmasının zorunlu olmadığ ${ }_{1}$ ifade edilmiştir. Bu ifadeye karşıllık, başka bir maddede "Etkinlikler, eğitim ortamının fiziksel koşulları, çocukların ilgi ve ihtiyaçları göz önünde bulundurularak yeniden düzenlenmelidir. Ancak ilgi ve ihtiyaçları karşıladığı takdirde birebir de kullanılabilir." açıklamasına yer verilmesi, sunulan etkinliklerin öğretmenlerin eğitimsel faaliyetlerine yön vermesi gerektiğini göstermektedir (EBA, 2018). Bakanlık, öğrenci kullanımına yönelik bir kaynak olarak "El Ele Okul Öncesi Eğitime" materyalini hazırlamıştır. Materyal ücretsiz dağıtılmış olup kullanımı zorunludur. Kullanımı zorunlu olan “El Ele Okul Öncesi Eğitime" materyalinin uygulanmasına dönük olarak öğretmenden, öncelikle Öğretmenler için Etkinlik Kitabı'nda yer alan etkinliklerin uygulanmasının, daha sonra El Ele Okul Öncesi Eğitime materyalinin kullanılmasının istenmesi de etkinliklerin eğitim akışının yönlendiricisi olduğunun bir başka kanıtıdır (EBA, 2018). Görüldüğü üzere kaynağın "uygulanmasının zorunlu olmadığı" etiketine rağmen mevcut durum uygulamadaki yönlendirici ve eğitim ortamını belirleyici rolünü gözler önüne sermektedir.

Özetle, Okul Öncesi Eğitim Programı'nın uygulamadaki yansımaları olan OBADER, Etkinlik Kitabı ve Öğretmenler İçin Etkinlik Kitabı'nın içeriğinde yer alan açık hava etkinlikleri öğrenme ortamı üzerindeki belirleyici gücü açısından kritik bir öneme sahiptir. Alat ve diğerleri (2012) çalışmasında, araştırmanın yapıldığı dönemde kullanılmakta olan 2006 Okul Öncesi Eğitim Programında açık hava etkinliklerine özel bir yer verilmediğini, uygulama kararının tamamen öğretmenlerin inisiyatifine bırakıldığını ifade etmiştir. Gerek ulusal gerekse uluslararası alanyazında yapılan araştırmalar, açık havada eğitimin çocuğun bütünsel gelişimi açısından vazgeçilmez bir öneme sahip olduğunu açıkça gözler önüne sermektedir. Ulusal alanyazında okul 
öncesi eğitimde açı hava etkinliklerine yönelik olarak öğretmen tutum ve uygulamalarını inceleyen (Alat ve diğerleri, 2012; Cetken ve Sevimli-Çelik, 2018; Çelik, 2012), açık alanların niteliğini belirlemeyi amaçlayan (Çelik, 2012; Orçan Kaçan, Halmatov ve Kartaltepe, 2017; Kalburan, 2014), çocukların "oyun" ve "bahçe" ile ilgili görüşlerinin incelendiği (Arabacı ve Çıtak, 2017), okul bahçelerinin ya da açık hava etkinliklerinin eğitsel amaçlı kullanımına yönelik öğretmen görüşlerini içeren (Civelek ve Akamca, 2017; Tepedağ ve Aktaş Arnas, 2017), bugünün çocuklarının açık hava oyun deneyimlerini geçmiş kuşaklar ile karşılaştıran (Aktaş Arnas ve Sarıbaş, 2020), çocukların açık hava oyun fırsatları ve bu konuyla ilgili ebeveyn görüşlerine yer veren (CevherKalburan, 2014), açık alan tasarımları sunan (Çukur, 2011) ve okul öncesi dönemde açık havada eğitime vurgu taşıyan alternatif uygulamaları içeren (Kahriman-Pamuk, 2020; Kahriman-Pamuk ve Ahi, 2019; Kanat, 2020; Koyuncu, 2019) çalışmalara rastlamak mümkündür. Ulusal alanyazında ayrıca okul öncesi eğitim programını çeşitli bileşenler üzerinden inceleyen çalışmalara da sıkça rastlanmaktadır (Aral ve Kadan, 2018; Baki ve Hacısalihoğlu-Karadeniz, 2013; Başaran ve Ulubey, 2018; Göle ve Temel, 2020; Kandır ve Türkoğlu, 2015; Keçecioğlu, 2015; Özsırkıntı, Akay ve Yılmaz Bolat, 2014; Tuğluk ve Özkan, 2019). Ancak okul öncesi eğitim programı ile açık hava etkinliklerini bir arada inceleyen herhangi bir çalışmaya rastlanmamıştır. Bu gerekçelerle öncelikle mevcut durumun belirlenebilmesi, ardından da gerekli önlemlerin alınabilmesi adına, ulusal eğitim politikamızın ilke, amaç ve uygulama örneklerinin ifadesi olan eğitim programı ve etkinlik kitaplarının sistematik incelenmesinde fayda vardır. Böylelikle ulusal eğitim programımızda açık havada eğitime atfedilen önemin artması ve sözü geçen engellerin ortadan kaldırılmasına yönelik destekleyici politikaların üretilmesi desteklenebilir. Bu bağlamda araştırmanın genel amacı, Okul Öncesi Eğitim Programı'nın uygulamadaki yansısını oluşturan OBADER, Etkinlik Kitabı ve Öğretmenler İçin Etkinlik Kitabı'nda yer verilen açık hava etkinliklerinin etkinlik çeşidi, gelişim alanı, konusu, ele aldığı kavram ve açık havanın etkinlikte konumlanma biçimi gibi değişkenler açısından sistematik olarak incelenmesidir.

Araştırmanın genel amacı doğrultusunda aşağıdaki sorulara yanıt aranmıştır:

1. Etkinlik Kitabı ve Öğretmenler için Etkinlik Kitabının açık havada yürütülmesi önerilen etkinliklerinin;
a. etkinlik çeşitlerine,
b. gelişim alanlarına,
c. ele alınan konulara,
d. ele alınan kavramlara ve
e. açık havanın konumlandırılmasına göre dağılımları nasıldır?

2. MEB Okul Öncesi Eğitim Programı'nın uygulamadaki yansısını oluşturan Etkinlik Kitabı ve Öğretmenler için Etkinlik Kitabı arasında, açık havada yürütülmesi önerilen etkinlikler açısından ne tür niceliksel farklılıklar vardır?

3. OBADER'de açık havada eğitimin önemine yönelik vurgu var mıdır?

\section{Yöntem}

\section{Araştırmanın Deseni}

Temel amacı, Okul Öncesi Eğitim Programı́nın uygulamadaki yansısını oluşturan Etkinlik Kitabı, OBADER ve Öğretmenler İçin Etkinlik Kitabı'nda yer verilen açık hava etkinliklerinin etkinlik çeşidi, gelişim alanı, konusu, ele aldığı kavramlar ve açık havanın etkinlikte konumlanma biçimi gibi değişkenler açısından sistematik olarak incelenmesi olan bu araştırmada nitel araştırma yöntemlerinden doküman incelemesi yöntemi kullanılmıştır. "Doküman incelemesi, araştıılması hedeflenen olgu ve olgular hakkında bilgi içeren yazılı materyallerin analizini kapsar." (Yıldırım ve Şimşek, 2011). Krippendorff'a (2004) göre ise doküman incelemesi çeşitli konulara yönelik metinlerden geçerli ve güvenilir sonuçlar çıarmak amacıyla kullanılabilecek bir yöntemdir.

Sosyal bilimlerin inceleme alanını oluşturan olgular, arkalarında çeşitli kanıtlar bırakırlar. Bu nedenle 
sosyal olgular araştırılırken, arkalarında bıraktıkları bu kanıtların incelenmeleri önemlidir. Bu bakımdan dokümanlar, sosyal olguların ardında kalan yazılı kanıtlar olarak değerlendirilebilir (Ulutaş, 2017). Bu araştırma kapsamında da Etkinlik Kitabı, OBADER ve Öğretmenler İçin Etkinlik Kitabı, Okul Öncesi Eğitim Programının yegâne uygulama materyalleri ve olgusal bir kanıtı olarak incelenmiş ve doküman incelemesi ile değerlendirilmiştir.

\section{Veri Kaynakları}

Araştırmada, 2013 Okul Öncesi Eğitim Programının materyallerini oluşturan, farklı yaş gruplarındaki çocuklar için 40 etkinlikten oluşan Etkinlik Kitabı, programla birlikte kullanılmak üzere hazırlanan OBADER ve Öğretmenler için Etkinlik Kitabı incelenmiştir.

Eğitim süreci içerisinde yürütülecek olan aile eğitimi çalışmalarına yönelik ilkeleri, uygulamaları, yöntem ve teknikleri, etkinlik, oturum ve katılım örneklerini içeren, bünyesinde video ve sunu gibi görsel dosyaları da barından OBADER, kapsamlı bir kaynaktır. Etkinlik Kitabı içerisinde sunulan etkinlikler 36-48 aylar aralığındaki farklı yaş gruplarına yönelik, Okul Öncesi Eğitim Programı'nda yer alan kazanım ve göstergeler ile kavramlar doğrultusunda hazırlanmıştır (MEB, 2013b). Sunduğu sınırlı sayıda (40 adet) etkinlik örneği dolayısıyla referans kaynaktan çok, örnek niteliğindedir. Bu sınırlı içeriğin yanı sıra programla ilgili verilen hizmet içi eğitimde de uygulama boyutunun yetersiz kalmasından dolayı yaşanan sıkıntılar Tükel (2017) tarafından da vurgulanmış ve daha kapsamlı kaynakların üretilmesine ihtiyaç duyulduğu belirtilmiştir.

Temel Eğitim Genel Müdürlüğü tarafından 2018 yılında, etkinlik havuzu oluşturulmasının önemi ve gerekliliği, izleme ve değerlendirme sonuçları, okul yöneticileri ve okul öncesi öğretmenlerinin geri bildirimleri, yanlış uygulama örneklerinin yer aldığı hazır planların yaygınlaşmış olması gibi nedenlerden dolayı öğretmene sınıf içi uygulamalarında rehber olacağı düşünülen Öğretmenler için Etkinlik Kitabı hazırlanmıştır. Bu kitapta yer alan 340 etkinlikte, Okul Öncesi Eğitim Programının temel ilkeleri benimsenmiş ve programda yer alan tüm kazanım ve göstergelere, belirli gün ve haftalara yer verilmiştir (EBA, 2018).

\section{Verilerin Toplanması}

Verilerin toplanması sürecinde, öncelikle çalışmanın temel belgelerini oluşturan üç doküman taranmış ve bu taramada açı havada yürütülmesi önerilen etkinlikler belirlenmiştir. İlgili etkinliklerin belirlenmesi sürecinde, öncelikle etkinliklerin her biri dikkatle okunmuştur. Bu ayrıntılı ve dikkatli okumada, etkinliğin ismi, etkinlik türü, materyaller (Etkinlik doğadan edinilen materyal içeriyor mu? İçeriyorsa bu materyallerin edinimi nasıl sağlanıyor? Çocuk ya da aile doğaya/açık havaya çıkıyor mu?) ve etkinlik içeriğinde herhangi bir açık hava (bahçe, park, orman, dışarıda/dışarısı vs.) vurgusu ya da ifadesinin olup olmadığına bakılmıştır. Yapılan incelemenin ardından OBADER'deki 62 etkinlikten bir tanesinin, Etkinlik Kitabı'ndaki 40 etkinlikten beş tanesinin ve Öğretmenler için Etkinlik Kitabı'ndaki 340 etkinlikten 27 tanesinin "açık hava etkinliği" olduğu belirlenmiştir. Ardından belirlenen etkinliklerin her biri yeniden ele alınıp çeşitli kategoriler altında tasnif edilmiştir.

\section{Verilerin Analizi}

Doküman incelemesi niteliğindeki bu araştırmada Etkinlik Kitabı, OBADER ve Öğretmenler için Etkinlik Kitabı kapsamında yer alan etkinlikler içerik analizi yöntemi kullanılarak analiz edilmiştir. İçerik analizinde yapılan işlem, benzer verileri kavramlar ve temalar çerçevesinde bir araya getirmek ve bunları okuyucunun anlayabileceği bir biçimde düzenleyerek yorumlamaktır (Yıldırım ve Şimşek, 2011). İçerik analizi, bir veya daha fazla sayıdaki metnin içindeki sözcüklerin, kavramların, temaların, karakterlerin, deyimlerin ya da cümlelerin varlıklarını belirlemek ya da onları sayısal olarak ifade etmek için kullanılır. Tüm bu içeriklerin yazıya dökülmüş olması gereklidir (Kızıltepe, 2017).

Yukarıdaki açıklamalar doğrultusunda, öncelikle çalışmanın dokümanlarını oluşturan üç kitap taranmış ve açık havada yürütülmesi önerilen etkinlikler belirlenmiştir. İncelenen dokümanlarda yer alan ve tasnifi yapılan etkinliklerin analiz edilmesi ve yorumlanması sürecinde kodlama, kategori geliştirme, frekansların hesaplanması ve yorumlama aşamaları takip edilmiştir. Bu amaçla öncelikle ilk taramada belirlenmiş olan, açı havada yürütülmesi önerilen etkinliklerin her biri dikkatlice incelenmiş ve bu etkinlikler etkinlik çeşidi, 
gelişim alanı, ele alınan kavram gibi kategoriler altında tasnif edilmiştir. Tüm bu kategorilerin belirlenmesinde, materyallerin kendisinde yer alan etkinlik künyeleri dikkate alınmıştır. Devamında belirlenen kategorilere dayalı frekanslar hesaplanmış ve elde edilen bulgular yorumlanmıştır.

Ardından etkinlikler ele aldıkları konular ve açık havayı kullanma şekli açısından kodlanmıştır. Bu kodlamanın yapılabilmesi için etkinlik içerikleri ayrıntılı şekilde okunmuştur. Elde edilen kodlar bir araya getirilip organize edilerek kategoriler oluşturulmuştur. Etkinliklerin araştırmacı tarafından incelenmesi sonrasında elde edilen kategoriler bir alan uzmanı bir de ölçme ve değerlendirme uzmanı tarafından incelenip değerlendirildikten sonra analiz edilmiştir. Analiz sürecinde her iki etkinlik kitabı da öncelikle kendi içinde, sonra da birbiriyle karşılaştırılarak değerlendirilmiştir. İçerik analizi süreci ve süreç sonucunda ortaya çıkan kategoriler Şekil 1'de yer almaktadır.

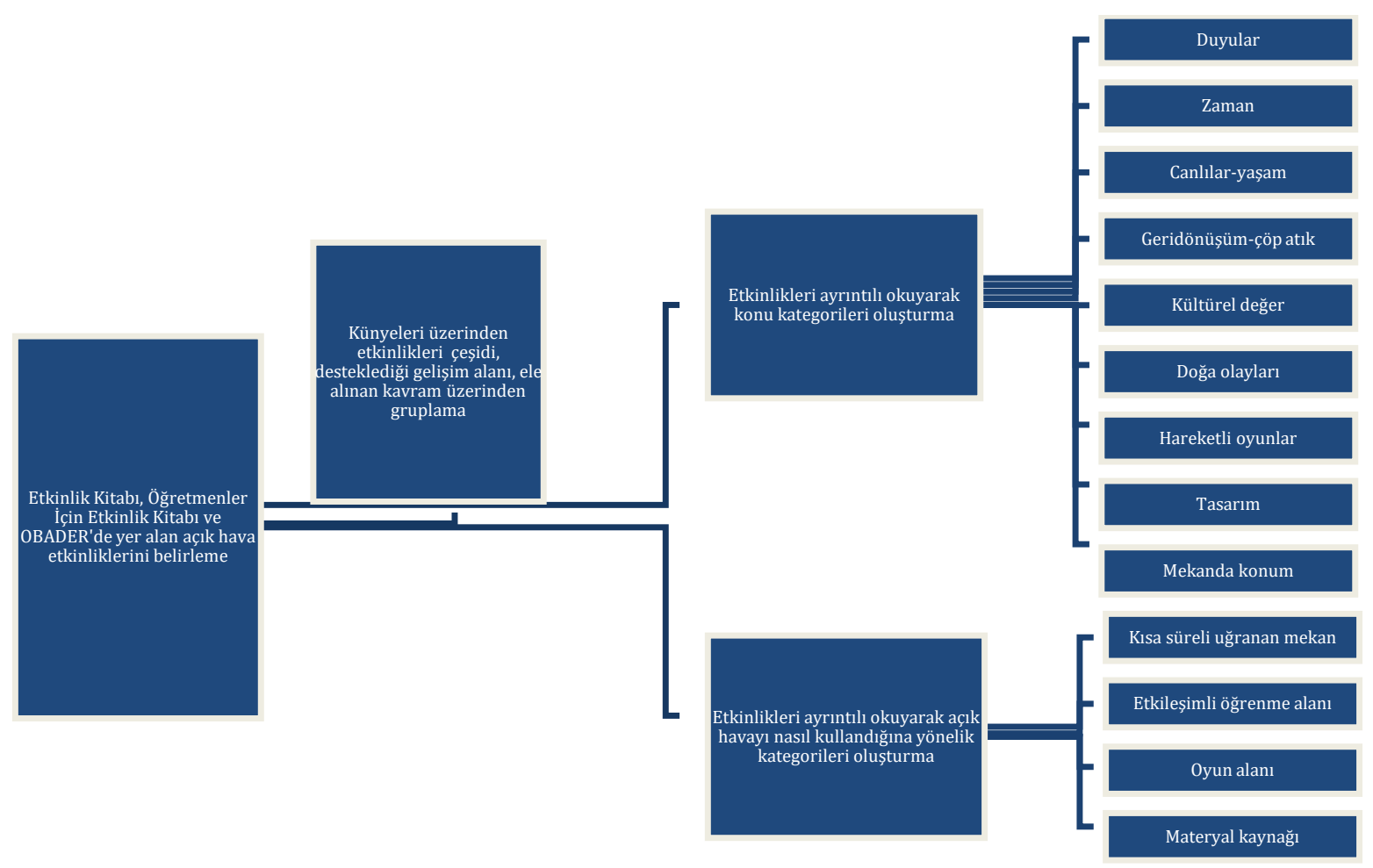

Şekil 1. İçerik analizi süreci.

\section{Bulgular}

Araştırmanın bulgular bölümünde, dokümanlarda yer alan etkinliklerin farklı değişkenler açısından yapılan analizleri ve elde edilen bulgular bulunmaktadır. Araştırma bulguları, frekans sonuçları şeklinde tablo haline getirilmiş ve tablo yorumları yapılmıştır.

Araştırmanın birinci alt amacına ilişkin olarak, Etkinlik Kitabı ve Öğretmenler İçin Etkinlik Kitabı'nın açık havada yürütülmesi önerilen etkinliklerinin, etkinlik çeşitlerine göre dağılımları Tablo 1'de gösterilmiştir. Her iki kitapta da açık havada yürütülmesi önerilen etkinlikler, birkaç etkinlik türünü birden içerebilmektedir. Örneğin, bir etkinlik aynı zamanda hem matematik hem de oyun etkinliği olabilmektedir. Böyle durumlarda incelenen etkinlik, içerdiği tüm etkinlik türleri üzerinden değerlendirilmiş ve tabloda da o şekilde sayısallaştırılmıştır.

Tablo 1

Etkinlik Kitabı ve Öğretmenler İçin Etkinlik Kitabı'nın Açık Havada Yürütülmesi Önerilen Etkinliklerinin Etkinlik Çeşitlerine Göre Dağılımları

\begin{tabular}{lcc}
\hline Etkinlik Çeşidi & Etkinlik Kitabı (5) & Öğretmenler İंcin Etkinlik Kitabı (27) \\
\hline Fen & 2 & 13 \\
Türkçe & 1 & 5
\end{tabular}




\begin{tabular}{lcc} 
Sanat & 3 & 14 \\
Hareket & - & 2 \\
Oyun & 1 & 10 \\
Matematik & 1 & 8 \\
Drama & - & 2 \\
Alan Gezisi & - & 7 \\
Okuma Yazmaya Hazırlık & - & 1 \\
Müzik & 1 & - \\
\hline
\end{tabular}

Tablo 1'de de görüldüğü gibi, her iki etkinlik kitabında da uygulama sıklığı açısından sanat etkinlik çeşidini fen etkinliği takip etmektedir. Öğretmenler İçin Etkinlik Kitabı'nda 27, Etkinlik Kitabı'nda 5 açık hava etkinliği olduğu düşünülürse, iki etkinlik çeşidine de yer verilme sıklığının oransal olarak benzer olduğu söylenebilir. Bunun dışında etkinlik sayıları göz önüne alındığında, her iki kitapta da hemen her etkinlik çeşidine yer verildiği görülmektedir. Hareket etkinlik çeşidine ise, doğası gereği açık havada yürütülmeye daha elverişli olmasına rağmen, Öğretmenler İçin Etkinlik Kitabı'nda yalnızca 2 kez yer verilirken, Etkinlik Kitabı'nda ise hiç yer verilmemesi şaşırtıcıdır.

Araştırmanın ikinci alt amacına ilişkin olarak, Etkinlik Kitabı ve Öğretmenler İçin Etkinlik Kitabı'nın açık havada yürütülmesi önerilen etkinliklerinin, gelişim alanlarına göre dağılımları Tablo 2' de gösterilmiştir. Her iki kitapta da açık havada yürütülmesi önerilen etkinlikler, birkaç gelişim alanını birden içerebilmektedir. Örneğin, bir etkinlik aynı zamanda hem bilişsel hem de dil gelişimini destekleyebilmektedir. Böyle durumlarda incelenen etkinlik, desteklediği tüm gelişim alanları üzerinden değerlendirilmiş ve tabloda da o şekilde sayısallaştırılmıştır.

Tablo 2

Etkinlik Kitabı ve Öğretmenler İçin Etkinlik Kitabı'nın Açık Havada Yürütülmesi Önerilen Etkinliklerinin Gelişim Alanlarına Göre Dağglımları

\begin{tabular}{lcc}
\hline Gelişim Alanları & Etkinlik Kitabı (5) & Öğretmenler İçin Etkinlik Kitabı (27) \\
\hline Motor Gelişim & 4 & 14 \\
Bilişsel Gelişim & 3 & 23 \\
Dil Gelişimi & 3 & 14 \\
Sosyal ve Duygusal Gelişim & 2 & 14 \\
Özbakım Becerileri & - & 2 \\
\hline
\end{tabular}

Tablo 2'de de görüldüğü gibi, her iki kitapta da hemen her gelişim alanına yer verilmiştir. Etkinlik Kitabı'nda özbakım becerilerine yönelik etkinliklere yer verilmezken, Öğretmenler İçin Etkinlik Kitabı'nda 2 etkinlikle de olsa yer veriliyor oluşu, çocukların bütünsel gelişimini desteklemesi adına olumlu bir gelişme olarak düşünülebilir. Özbakım becerileri dışında, gelişim alanlarının her iki kitapta da dengeli bir dağılım gösterdiği söylenebilir. Etkinlik Kitabı'nda baskın gelişim alanı motor gelişim iken Öğretmenler İçin Etkinlik Kitabı'nda ise bilişsel gelişim oluşu, açık hava etkinliklerine yönelik bakış açısında bir değişim olarak yorumlanabilir. Ayrıca Etkinlik Kitabı'nda yer alan açık hava etkinliklerinde baskın gelişim alanının motor gelişim olmasına rağmen, bu etkinliklerden hiçbirinin hareket etkinlik çeşidinde olmaması ise ilginç bir durumdur.

Araştırmanın üçüncü alt amacına ilişkin olarak, Etkinlik Kitabı ve Öğretmenler İçin Etkinlik Kitabı'nın açık havada yürütülmesi önerilen etkinliklerinin, konularına göre dağılımları Tablo 3'te gösterilmiştir. Her iki kitapta da açık havada yürütülmesi önerilen etkinlikler, birkaç konu kategorisini birlikte içerebilmektedir. Örneğin bir etkinlik aynı zamanda hem tasarım hem de canlılar-yaşam konu kategorisini içerebilmektedir. Böyle durumlarda incelenen etkinlik, içerdiği tüm kavram kategorileri üzerinden değerlendirilmiş ve tabloda da o şekilde sayısallaştırılmıştır.

Tablo 3

Etkinlik Kitabı ve Öğretmenler İçin Etkinlik Kitabı'nın Açık Havada Yürütülmesi Önerilen Etkinliklerinin Konularına Göre Dağılımları

\begin{tabular}{lcc}
\hline Konu Kategorileri & Etkinlik Kitabı (5) & Öğretmenler İçin Etkinlik Kitabı (27) \\
\hline Duyular & - & 2 \\
Zaman & 1 & 3 \\
Canlılar-Yaşam & 1 & 6 \\
Geridönüš̈m-Çöp-Atık & - & 3 \\
Kültürel Değer & - & 4
\end{tabular}


Açık Havada Eğitim: Okul Öncesi...

Doğa Olayları

Hareketli Oyunlar

Tasarım

Mekânda Konum
2

Tablo 3'te de görüldüğü gibi, her iki kitapta da yer alan açık hava etkinlikleri konuları açısından incelendiğinde, elde edilen kategoriler arasında "canlılar ve yaşam" ve "hareketli oyunlar" baskın olarak göze çarpmaktadır. "Canlılar ve yaşam" kategorisi, yaşamın kaynağının doğa olması, "hareketli oyunlar" kategorisi ise açık havanın sunduğu geniş mekân ve hareket/gürültü özgürlüğü nedeniyle beklenen bir durumdur. Şaşırtıcı olan durum ise, açık hava ortamlarının doğal olarak vadettiği zengin duyusal deneyimlere rağmen "Duyular" konu alanının en az ele alınan konu başlığı olmasıdır. Etkinlik Kitabı'nda ele alınmayan pek çok konunun, sonrasında hazırlanan Öğretmenler İçin Etkinlik Kitabı'nda ele alınmış oluşu ise olumlu bir gelişme olarak değerlendirilebilir.

Araştırmanın dördüncü alt amacına ilişkin olarak, Etkinlik Kitabı ve Öğretmenler İçin Etkinlik Kitabı'nın açık havada yürütülmesi önerilen etkinliklerinin, ele aldıkları kavramlara göre dağılımları Tablo 4'te gösterilmiştir. Her iki kitapta da açık havada yürütülmesi önerilen etkinlikler, birkaç kavram kategorisini birden içerebildiği gibi herhangi bir kavram kategorisini içermeyebilmektedir. Daha açık ifade etmek gerekirse bir etkinlik, aynı anda hem geometrik şekil hem de boyut kavram kategorilerini içerebilirken, başka bir etkinlik hiçbir kavram kategorisini içermeyebilir. Böyle durumlarda incelenen etkinlik, içerdiği tüm kavram kategoriler üzerinden değerlendirilmiş ve tabloda da o şekilde sayısallaştırılmıştır.

Tablo 4

Etkinlik Kitabı ve Öğretmenler İçin Etkinlik Kitabı'nın Açık Havada Yürütülmesi Önerilen Etkinliklerinin Kavramlara Göre Dağıllmmları

\begin{tabular}{lcc}
\hline Kavram Kategorileri & Etkinlik Kitabı (5) & Öğretmenler İçin Etkinlik Kitabı (27) \\
\hline Geometrik Şekil & - & 1 \\
Boyut & 1 & 4 \\
Miktar & - & 4 \\
Mekânda Konum & 1 & 3 \\
Sayı/Sayma & - & 3 \\
Duyu & - & 6 \\
Zit & 2 & 4 \\
\hline
\end{tabular}

Tablo 4'te her iki kitapta açık havada yürütülmesi önerilen etkinliklerin kavram kategorilerine göre dağılımı incelendiğinde, Öğretmenler İçin Etkinlik Kitabı'nda daha fazla kavram çeşidine yer verildiği görülmektedir. Bu bulgu, Öğretmenler İçin Etkinlik Kitabı'nda bilişsel gelişim alanına artan düzeyde verilen önemle örtüşür niteliktedir (bknz. Tablo 2). Açık hava etkinliklerinin duyuların kullanımına yönelik sunduğu fırsatlar göz önüne alındığında, duyu kavram kategorisine yer veriş oranlarının azlığı ise düşündürücüdür.

Araştırmanın beşinci alt amacına ilişkin olarak, Etkinlik Kitabı ve Öğretmenler İçin Etkinlik Kitabı'nın açık havada yürütülmesi önerilen etkinliklerinde, açık havanın konumlandırılmasına göre dağılımları Tablo 5 'te gösterilmiştir.

Tablo 5

Etkinlik Kitabı ve Öğretmenler İçin Etkinlik Kitabı'nın Açık Havada Yürütülmesi Önerilen Etkinliklerinin Açık Havanın Konumlandırılmasına Göre Dağılımları

\begin{tabular}{lcc}
\hline Açık Havanın Konumu & Etkinlik Kitabı (5) & Öğretmenler İçin Etkinlik Kitabı (27) \\
\hline Kısa Süreli Uğranan Mekân Olarak & - & 3 \\
Etkileşimli Öğrenme Alanı Olarak & 3 & 13 \\
Oyun Alanı Olarak & 1 & 6 \\
Etkinlik Materyalinin Kaynağı Olarak & 1 & 5 \\
\hline
\end{tabular}

Tablo 5'te de görüldüğü gibi, her iki etkinlik kitabında da açık havanın etkileşimli öğrenme alanı olarak konumlandırılması baskındır. Bu durum, alanyazının açık havada eğitime verdiği önemi destekler niteliktedir. Açık hava kullanımında en az düzeyde ise "kısa süreli uğranan mekân olarak" kategorisi yer almaktadır. Bu kategoride yer alan etkinliklerde açık hava, yapılan kuş yemliğinin bahçedeki ağaca asılıp sınıfa geri dönülmesi gibi anlık açık hava erişimlerini tanımlamaktadır. Bu nedenle, açık hava etkinliği olarak değerlendirilmemesi bile düşünülebilir. 
Araştırmanın ikinci amacı, MEB Okul Öncesi Eğitim Programı'nın uygulamadaki yansısını oluşturan Etkinlik Kitabı ve Öğretmenler için Etkinlik Kitabı arasında, açık havada yürütülmesi önerilen etkinlikler açısından ne tür niceliksel farklılıklar olduğunu sorgulamaktadır. Elde edilen bulgulara Tablo 6'da yer verilmiştir.

\section{Tablo 6}

Etkinlik Kitabı ve Öğretmenler İ̧cin Etkinlik Kitabı'nın Açık Havada Yürütülmesi Önerilen Etkinliklerinin Niceliksel Farklılıları

\begin{tabular}{lcc}
\hline Nicel Veriler & Etkinlik Kitabı & Öğretmenler İçin Etkinlik Kitabı \\
\hline Kitaptaki Toplam Etkinlik Sayısı & 40 & 340 \\
Açık Havada Geçirilmesi Önerilen Etkinlik Sayısı & 5 & 27 \\
Açık Havada Geçirilmesi Önerilen Etkinlik Yüzdesi & $\% 12.5$ & $\% 7.9$ \\
\hline
\end{tabular}

Tablo 6'da da görüldüğü gibi, araştırmanın ikinci amacına ilişkin olarak etkinlik kitapları, açı havada yürütülmesi önerilen etkinliklerinin niceliksel farklılıkları açısından karşılaştırıldığında, Etkinlik Kitabı'nda yer alan 40 etkinlikten 5 tanesinin, Öğretmenler İçin Etkinlik Kitabı'nda yer alan 340 etkinlikten 27 tanesinin açık hava etkinliği olduğu görülmüştür. Açık hava etkinliklerine yer veriş sayısı yüzde olarak değerlendirildiğinde ise bu oran, Etkinlik Kitabı'nda \%12,5 iken, Öğretmenler İçin Etkinlik Kitabı'nda ise \%7,9'dur. 2013 Okul Öncesi Eğitim Programının öğretmenlere etkinlik önerilerini içeren ilk materyal olan Etkinlik Kitabı, sunduğu sınırlı sayıda (40 adet) etkinlik örneği nedeniyle Temel Eğitim Genel Müdürlüğü tarafından 2018 yılında güncellenmiştir. Bu güncellemeyle önerilen etkinlik sayısının 340'a çıkarılarak 8,5 kat arttırılması, Öğretmenler için Etkinlik Kitabı'nın programda yer alan tüm kazanım ve göstergelere, belirli gün ve haftalara yer veren bir yapıya kavuşmasını sağlamıştır. Bu yapı ile MEB -her ne kadar örnek olarak sunulduğu ifade edilse de- hem okul öncesi eğitimden hem de öğretmenlerin sürdüreceği etkinliklerden ne beklediğini göstermektedir. Bu beklenti sonucunda, Etkinlik Kitabı'nda alana sunulan etkinlik sayısı 40 iken, Öğretmenler İçin Etkinlik Kitabı'nda bu sayı 340'a yükseltilerek yaklaşık 8,5 kat arttırılmış olmasına rağmen, artan bu oran açık hava etkinliklerine yansıtılamamıştır. Oransal olarak görülen bu azalış, programda ve alanyazında açık hava etkinliklerinin vurgulanan öneminin uygulamaya yansıtılamadığının göstergesidir.

Araştırmanın üçüncü amacına ilişkin olarak OBADER, içeriğinde açık havada eğitimin önemine yönelik herhangi bir vurgu olup olmaması açısından değerlendirilmiştir. Yapılan incelemede "Aileler; alan gezileri ve açık hava etkinliklerinde çocukları gözetim altında bulundurabilirler..." (MEB, 2013c) ifadesi dikkat çekici bulunmuştur. $\mathrm{Bu}$ ifade, alan gezileri ve açı hava etkinliklerinin tehlikeli olabileceği mesajını vererek, çocukların bu etkinliklerde "gözetim altında" tutulması gerektiğini ifade etmektedir. Bu ifadede sunulan olumsuz mesaj, ailelerin daha da korumacı/evhamlı olmasına sebep olup açık hava etkinliklerinin arttırılmasına ket vurabilir.

Açık hava etkinliklerine yönelik aile katılımları için yer verilen bir diğer ifade ise "Sosyal etkinlikler, alan gezileri, açık hava etkinliklerinde öğretmene yardımcı olması" vurgusudur (MEB, 2013c, s. 77). Aslında bu ifadede asıl amaç, aileyi açık hava ve okul dışı eğitim ortamlarına katılmaya teşvik etmektir. Ancak böyle bir vurgu, açık hava ya da okul dışı öğrenme ortamlarına yönelik etkinlik ve organizasyonların zor olduğu, böyle etkinliklerde öğretmenin yardıma ihtiyaç duyduğu algısına sebep olabilir. Bu algı da bu tür etkinliklere karşı temkinli ya da önyargılı olmaya sebebiyet verebilir.

Açık hava etkinlikleri ile ilgili olarak OBADER'de rastlanan bir başka vurgu ise "oyun etkinliği" başlığı altındaki açılamalarda yer almaktadır (MEB, 2013c, s. 22). Burada, "iç mekânlarda çocukların yaşlarına, gelişimsel gereksinimlerine ve ilgilerine göre farklı oyun fırsatları sunulmasının yanı sıra, dışarı oyun alanlarında da sağlanacak oyun fırsatlarının çocukların gelişimlerini bütünsel olarak desteklediği" ifadesine yer verilmiştir. Benzer şekilde okulun eğitim programına ilişkin bilgilerin verildiği bölümde de (MEB, 2013c, s. 99) "Etkinlik uygulamaları sınıf içinde olduğu kadar açık havada da yapılmalıdır." ifadesine yer verilmektedir. Başka bir ifadeyle OBADER bu açıklamalarla açık hava etkinliklerinin gerekliliğini ve çocuğun bütüncül gelişimini desteklediğini savunmuştur. Bu savunuya rağmen içeriğinde aile eğitimi ve katılımına yönelik 62 etkinlikten yalnızca bir tanesi (s. 77) açık hava etkinliğidir. Bu etkinlik, fen etkinliği olarak sunulmuştur ve okul bahçesini düzenlemeye yöneliktir. Etkinlik içeriğinde ailelerden bitki tohumlarının ve 
çiçek fidelerinin talep edilmesi, çocuklarla beraber bahçenin ekim için hazırlanması, çiçek/bitki tohum ya da fidelerinin ekilmesi ve sürecin takip edilmesi yer almaktadır.

\section{Sonuç ve Tartışma}

$\mathrm{Bu}$ araştırmada, Okul Öncesi Eğitim Programı'nın uygulamaya dönük materyallerindeki açık hava etkinliklerinin etkinlik çeşidi, gelişim alanı, konusu, ele aldığı kavramlar ve açık havanın etkinlikte konumlanma biçimi değişkenleri açısından sistematik olarak incelenmesi amaçlanmaktadır. Doküman incelemesi niteliğindeki bu araştırmada, Okul Öncesi Eğitim Programının materyallerini oluşturan Etkinlik Kitabı, OBADER ve Öğretmenler için Etkinlik Kitabı incelenmiştir.

Etkinlik türlerinde çeşitlilik yaratmak, çocuklara farklı öğrenme deneyimleri yaşattığı gibi öğrenme ortamlarını da zenginleştirir. $\mathrm{Bu}$ araştırmada incelenen etkinlik kitaplarında açık havada yürütülmesi önerilen etkinliklerin çeşitlerine göre dağılımına bakıldığında en sık sanat, en seyrek ise okuma yazmaya hazırlık ve müzik etkinliklerinin olduğu görülmektedir. Davies'in (1996) de ifade ettiği gibi, açık hava ortamları sağladığı farklı aktivite seçenekleri ile iç mekâna göre çok daha zengin öğrenme fırsatları sunar. Açık havada sağlanan deneyimler, genelde iç mekânlara özgü olduğu düşünülen sanat, müzik ya da hikâye anlatımı gibi etkinlikleri de içerebilir. Kiewra ve Veselack'ın (2016) yapmış olduğu araştırmaya göre doğal açık hava sınıfları, bu alanları kullanan çocukların estetik ve yaratıcılık da dahil olmak üzere tüm öğrenme alanlarını desteklemektedir. Bir diğer araştırmada ise çocuklar, açık havada doğal materyallerle eşleştirmeleri ve serileri deneyimlerken matematiksel ve bilimsel düşünceyi kullanır, neden ve sonuç ilişkisi kurar ve açık hava çevresindeki elementleri tanırlar (Burdette ve Whitaker, 2005b). Ayrıca açık hava ortamları, çocuklara iç mekân sınıflarına göre daha fazla duyusal deneyim yaşatır. Çocuklar açık havada elementlerle ve doğanın kendisiyle daha fazla etkileşim halinde olurlar. Özetle, açık hava iç mekâna göre sağladığı farklı aktivite seçenekleri ile programda yer alan ya da almayan tüm öğrenme alanlarını destekleyecek eşsiz öğrenme fırsatları sunar (Davies, 1996). Çocukların açık hava ortamlarındaki bu zengin öğrenme olanaklarından yararlanabilmeleri için, program materyallerinde yer verilen etkinliklerin çeşitleri arttırılarak öğretmenlere açık hava öğrenme ortamlarını zenginleştirebilecekleri seçenekler sunulabilir. Böylece öğretmenler açık hava ortamlarını daha etkin kullanabilirler.

Araştırma kapsamında incelenen bir diğer değişken gelişim alanlarıdır. Program kitaplarında açık havada yürütülmesi önerilen etkinliklerin gelişim alanlarına göre dağılımına bakıldığında Etkinlik Kitabı'nda en fazla motor gelişim alanının desteklendiği, Öğretmenler İçin Etkinlik Kitabı'nda ise en fazla bilişsel gelişimin desteklendiği görülmektedir. Her iki kitapta da özbakım becerileri, en az desteklenen gelişim alanıdır. Öğretmenlerin açık hava etkinliklerine yönelik bakış açısını sorgulayan çeşitli araştırmalarda da açık hava etkinliklerinin sadece fiziksel gelişimi desteklediği düşüncesinin baskın olduğu ortaya konmuştur (Bilton, 2010; Frost ve Wortham,1988; Rivkin, 1998). Oysaki açık havada oyun, sağladığı fiziksel refah (Hetherington, 2001), duygusal ve sosyal gelişim (Millward ve Whey, 1997), karmaşık dil ve konuşma becerileri olanağı sunan etkinlikler (Bohling, Saarela ve Miller, 2010) ve daha derin öğrenme seviyeleri (Laevers, 2000) sayesinde çocuğun bütüncül gelişimine katkı sunar (Wilson, 2008). Benzer şekilde Olsen ve Smith (2017) de açık havada oyun oynamasına ve vakit geçirmesine izin verilen çocukların fiziksel, sosyal, duygusal ve entelektüel olarak geliştiğini ifade etmektedir. Açık hava ortamları çocukların büyümelerine yardımcı olduğu gibi tüm gelişim alanlarının da desteklenmesini sağlar (Wilson, 2008). Ayrıca çocuklar için deney, keşif ve araştırma temelli öğrenme ortamları sunar. Çocukların dil becerileri, bilişsel becerileri, motor becerileri doğayla etkileşim sonucunda daha iyi gelişir. Açık hava anti-sosyal davranışlarda azalmayı sağlarken; iş birliği, dayanışma, uzlaşma, çatışma çözme becerilerinde ise artışa sebep olur (Burdette ve Whitaker, 2005a). Bu nedenlerle okul öncesi programı ve materyalleri, tüm gelişim alanlarını desteklemeye dönük açk hava etkinlikleriyle zenginleştirilmelidir.

Açık hava ortamlarının sunduğu zengin olanaklar, çocukların hayal gücü ve merakı ile birleşince sonsuz etkinlik olasılıklarına kapı açabilir. Bu araştırmada incelenen etkinlik kitaplarında açık havada yürütülmesi önerilen etkinlikler konularına göre incelendiğinde, en yaygın konu alanının "canlılar-yaşam" ve "hareketli oyunlar" olduğu görülmektedir. Doğa ve açık alanlar, "canlı"ların temel yaşam alanı olması nedeniyle, elde 
edilen bulgu şaşırtıcı değildir. Çocuklar, bitkilerle, hayvanlarla ve doğa ile karşı karşıya kaldıklarında gözlemlemek, incelemek, karşılaştırmak ve denemek için kendiliğinden motive olurlar (Jacobi-Vessels, 2013). Gardner'a (2000) göre, doğayı bilmek-yorumlamak kendi başına bir zekâ göstergesi olarak tanımlanmalıdır. Doğa zekâsı bitkileri, hayvanları ve onların çevrenin diğer bölümleriyle olan ilişkilerini tanımlama ve anlama yeteneğini içerir. Açık hava öğrenme ortamları, bu zekâ türünü doğal olarak destekler. Çevresindeki canlıları tanıyan ve değer veren çocukların, çevreyi korumanın yollarını bulma olasılıkları daha yüksek olabilir (Blanchard ve Buchanan, 2011). Bu açıdan açık hava etkinliklerine daha sık ve yoğun yer verme, çevre eğitimi kapsamında da destekleyici sonuçlar doğurabilir. Etkinlik kitaplarında hareketli oyunların açı hava etkinlikleri kapsamında sıkça öneriliyor oluşu ise açık havanın sunduğu geniş mekân ve gürültü serbestliği (Davies, 1996; Hearron ve Hildebrand, 2013) ile tepeler, ağaçlar ve çukurlar gibi hareketi destekleyici doğal platformlar (Fjortoft, 2001) ile açıklanabilir. Açık hava ortamlarının doğal olarak vadettiği zengin duyusal deneyimlere rağmen "Duyular" konu alanının en az ele alınan konu başlığı olması ise oldukça şaşırtıcıdır.

Okul öncesi dönem, düşünme ve öğrenme becerilerinin temelinin atıldığ1 yegâne zaman dilimidir. Çocuklar bu becerileri kullanarak neden, niçin, nasıl gibi sorulara mantıklı cevaplar vermeye çalışırken kavramları, kavramlar arasındaki ilişkileri ve akıl yürütmeyi öğrenirler (Çamlıbel-Çakmak, 2018). Yer, zaman, miktar ve sınıflama gibi temel kavramlar çocuğun düşünme becerileri için temeldir. Boehm'e (2000) göre, çocuklar kavramlar yoluyla nesneler arasındaki ilişkileri, yer ve mekân özelliklerini, olayların sırasını anlamlandırabilirler (akt. Çamlıbel-Çakmak, 2018). Araştırma kapsamında incelenen etkinlik kitaplarında açık havada yürütülmesi önerilen etkinlikler, ele alınan kavram grubuna göre değerlendirildiğinde en sık "zıt kavramlar", en az ise "geometrik şekiller" kavram grubunun ele alındığı; "duyular" kavram grubuna ise oldukça sınırlı düzeyde yer verildiği görülmektedir. Oysaki çocuklar açık havada yürütülen etkinliklerde, duyulara yönelik farklı koku, doku, ses, renk ya da tatlardaki nesne ve varlıklarla kurulan etkileşimle zengin öğrenme deneyimleri yaşarlar (Davies, 1996). Ancak McClintic ve Petty'nin (2015) de ifade ettiği gibi öğretmenler açık havada oyunun çocuklar için gelişimsel değerini önemli bulmakla birlikte, açık havada yürütülebilecek öğrenme etkinlikleri hakkındaki bilgi ve motivasyonlarını yetersiz olarak nitelendirmektedirler. Bu nedenle, öğretmenlerin açık havada yürütülebilecek öğrenme etkinliklerini planlama ve yürütme konusunda çeşitli eğitimlerle desteklenmesi ve programın müfredat yönünü oluşturan materyallerin, öğrenme içeriği yönünden zenginleştirilmesi önemlidir.

Öğrenme etkinliklerinin düzenlenmesinde açık havanın mekân olarak ne şekilde konumlandırıldığı, ona atfedilen değerin bir yansıması olarak düşünülebilir. Okul Öncesi Eğitim Programı materyallerinde yer alan etkinliklerde açık havanın konumlandırılma şekline bakıldığında ise en yaygın konumlandırmanın "etkileşimli öğrenme alanı" olduğu görülürken, en seyrek konumlandırmanın ise "kısa süreli uğranan mekân" olduğu görülmektedir. Alat ve diğerleri (2012) araştırmasında, öğretmenlerin çocuklarla birlikte açık havada gözlemleme, keşfetme, tartışma gibi öğrenme etkinliklerini yürütmek yerine açık havayı sadece bir oyun alanı ya da etkinliklerin materyal kaynağı olarak görme eğiliminde olduğunu bulgulamıştır. Bu bakış açısı doğanın/bahçenin/açık havanın öğrenme etkinliğinin öznesi olmaktan ziyade, materyal sağlanan alan/mekân olarak nesneleştirildiği, malzeme deposu olarak konumlandırıldığı şeklinde yorumlanabilir. Etkinlik kitaplarında açı havanın etkileşimli öğrenme ortamı olarak konumlandırılması, bu eğilimde değişiklik yaratabilecek olumlu bir gelişme olarak değerlendirilebilir.

Okul öncesi eğitimin planlanması ve yürütülmesinde, açık hava etkinliklerine düzenli ve yeterli miktarda yer verilmesi, çocukların sağlıklı yetişmelerini desteklediği gibi, doğayı/çevreyi seven, önemseyen ve onu korumak için çaba gösteren bireylerin yetiştirilmesini sağlamak adına da önemlidir. Araştırma kapsamında ele alınan ilgili dokümanların tamamı incelendiğinde, 2013 yılında uygulamaya sunulan Etkinlik Kitabı'nda 40 etkinlikten beş tanesinin (\%12,5), 2018 yılında uygulamaya sunulan Öğretmenler İçin Etkinlik Kitabı'nda ise 340 etkinlikten 27 tanesinin $(\% 7,9)$ açık hava etkinliği olduğu belirlenmiştir. Bu oranlar oldukça düşüktür. Elde edilen bulgularda da görüldügü gibi, okul öncesi eğitim programında açık havada eğitimin önemi ve gerekliliğine yapılan vurguya rağmen, etkinlik materyallerinde açık hava etkinliklerine özel bir yer verilmemiş ve sunulan sınırlı etkinlik örnekleriyle uygulayıp uygulamamak tamamen öğretmenlerin tercihine bırakılmıştır. Okul öncesi dönem, öğrenmenin en yoğun olduğu, çocukların çevrenin tüm olumlu ve olumsuz 
etkilerine açık olduğu bir dönemdir (Babaroğlu, 2018). Dolayısıyla bu dönemde, zengin fiziksel ve sosyal çevrenin sunduğu deneyimleri öğrenme ortamlarına getiren, gelişime uygun uygulamalara ihtiyaç vardır. Küçük Çocukların Eğitimi Ulusal Birliği (NAEYC), Gelişimsel Açıdan Uygun Program kavramını örneklendirilerek açıklamıştır (Bredekamp, 2015). Gelişimsel Açıdan Uygun Program, çocukların gelişim, büyüme ve ilgi düzeylerini dikkate alan ve bu durumu program temeline yerleştiren müfredatların ortak adı olarak kullanılmaktadır (Bredekamp, 2015). Dewey tarafından yöneltilen "Çocuklar nasıl öğrenir?" ve "Öğretme nasıl olmalıdır?" soruları, Gelişimsel Açıdan Uygun Programa dair uygulamaların temelini oluşturmaktadır. Gelişimsel Açıdan Uygun Programlar çocuğu bütüncül olarak ele alır. Çocuk tarafından başlatılan etkinlikleri önemli bulur. Oyunu önemli bir öğrenme aracı olarak kabul eder (Kostelnik, Sodelman, Whiren ve Rupiper, 2019). Bahsedilen tüm bu özellikler etkili açık havada eğitim uygulamalarının çocuklara sunduğu bileşenlerdir (White, 2008). Öğretmenlerin bahsedilen bu etkili açık hava etkinlik ve uygulamalarını yaratabilmesi için, okul öncesi eğitim programının sadece "ne yapılmalı?" sorusunun cevabını verip teorik bilgileri barındıran program metin içeriğiyle değil, "ne şekilde ve nasıl yapılmalı?" sorusunun cevabını veren etkinlik örnekleriyle de desteklenmesi önemlidir.

Çocuklar zamanlarının ve yaşantılarının büyük bir kısmını aileleriyle geçirirler. Bu nedenle aile, çocuğun potansiyelini ortaya koymada, kendini gerçekleştirmesinde, akademik ve sosyal gelişiminin tamamlanmasında büyük bir güce sahiptir. Bu nedenle çocuk için okul ve aile ortamının ortak amaçları ve yaklaşımları benimseyip sergilemesi önemlidir. Ortak amaç ve yaklaşımların belirlenmesi, uygulanması ve değerlendirilmesinde ise aile eğitimi ve katılımı çalışmaları önem kazanmaktadır (MEB, 2013c). Okul Öncesi Eğitim Programının aile eğitimi boyutunu oluşturan materyali olan OBADER, bünyesinde 40 adet aile katılım etkinliği barındırmaktadır. Araştırma kapsamında yapılan incelemede 40 aile katılım etkinliğinden sadece bir tanesinin açık havada yürütülen etkinlik olduğu belirlenmiştir. Aile katılımı çalışmalarıyla okul ve ev arasında iş birliğinin sağlanması ve böylece çocukların gelişimlerinin ve eğitimlerinin desteklenmesi amaçlanır (Çamlıbel-Çakmak, 2010). Ayrıca, okulda verilen eğitimin, okul dışında da sürdürülmesi, eğitimin kalıcılığını arttıracağı için aile eğitimi ayrı bir önem taşımaktadır (Tezel Şahin ve Cevher Kalburan, 2009). Açık havada yürütülmesi önerilen etkinliklerin böylesi sınırlı miktarda olması, dönem çocuğunun açık havanın yaratacağı gelişimsel fırsatlardan yararlanmasını destekleyemeyeceği gibi, ailenin bakış açısını da açık havaya erişim lehine değiştiremeyeceği açıktır. Ayrıca yapılan incelemede, açık hava ve okul dışı eğitim etkinliklerinin planlanması ve sürdürülmesine yönelik açıklamalarda, ebeveynlere konuyla ilgili olumsuz mesaj verebilecek çeşitli ifadelere rastlanmıştır. Alat ve diğerlerinin (2012) araştırmasında öğretmenler, velilerin açık havaya erişimle ilgili verdikleri olumsuz tepkileri, açık havada eğitime yeteri kadar yer vermemelerinin gerekçelerinden biri olarak ifade etmişlerdir. Benzer sonuçlara gerek ulusal gerekse uluslararası alanyazında rastlamak mümkündür (Çelik, 2012; Maynard ve Waters, 2007; Waite, 2010; Wilson, 2008). OBADER, okul öncesi eğitim programı ile aile eğitimlerini bütünleştiren bir kılavuzdur. Çocuklarımızın doğayla bağ kurmasının en etkili yolu, bu bağı ilk olarak onu büyüten yetişkinler olarak aile bireylerinin kurmasıdır (Erol ve Gülay Ogelman, 2019; Louv, 2010). Ancak, bu ilgi ya da istek aile bireylerinde yoksa verilecek etkili bir aile eğitimi işe koşulabilir. Erol ve Gülay Ogelman'ın (2019) yürüttüğü deneysel çalışmada aile katılım etkinliklerinin, çevreye yönelik davranış, düşünce ve tutum toplam puanlarında olumlu anlamlı farklılık yarattığını göstermektedir. Benzer şekilde Payne (2010) da okul öncesi eğitimdeki aile katılımı çalışmaları ile ebeveynlerin çevreye yönelik bilgi ve bilinç düzeylerinde artış görülebildiğini ifade etmiştir. Başka bir ifadeyle etkili ve amaçlı hazırlanmış bir aile eğitim programı ile çocukların açık havaya erişiminin önündeki engellerin kaldırılabilir. Ancak program kapsamında açık havada yürütülen bir etkinlik, arzulanan bu gelişim ve değişimin sağlanabilmesi için elbette ki yeterli değildir. Aile katılımı kapsamında yürütülen etkinliklerin, açık havayı etkileşimli öğrenme alanı olarak ele alan, çeşitlendirilmiş ve zenginleştirilmiş etkinlikler olarak yenilenmesine ihtiyaç olduğu açıtır.

Yapılan araştırma, Okul Öncesi Eğitim Programının materyallerini oluşturan Etkinlik Kitabı, OBADER ve Öğretmenler için Etkinlik Kitabında yer verilen açık hava etkinlikleri ile sınırlıdır. Ulusal uygulamalara yönelik daha ayrıntılı bilgi elde etmek ve mevcut uygulamaları incelemek için, okul öncesi öğretmenleri tarafından hazırlanan öğrenme akışları incelenebilir; öğretmen görüş ve uygulamalarına başvurulabilir. 
İhtiyaç duyulan paradigma değişiminin sağlanarak açık havada eğitimin kritik faydalarından yararlanılabilmesi için öğretmen eğitimleri, ortam tasarımları elbette önemlidir. Ancak bu değişimin sağlanabilmesi hem uzun soluklu bir süreci hem de geniş ölçekli bir maddi yatırımı gerektirmektedir. Bu nedenle, öncelikli eylem planı dâhilinde, eğitimcilere yön verme ve süreç içerisinde tutum geliştirme amacıyla, okul öncesi eğitim programı ve uygulamaya dönük materyallerinde yer alan açık hava etkinliklerinin sayı ve çeşitlilik olarak zenginleştirilmesi yerinde bir uygulama olacaktır. Başka bir ifadeyle, Okul Öncesi Eğitim Programı ve materyallerinin güncellenmesi sürecinde, politika belirleyicilerin, akademisyenlerin ve eğitimcilerin gerek program gerekse etkinlikleri yeniden planlarken açık havada eğitimin vazgeçilmez faydalarını göz önünde bulundurması ve bu farkındalığı gerek nicelik gerekse nitelik açısından ilgili dokümanlara yansıtması önerilmektedir. Açık hava etkinlikleri okul öncesi eğitim programının bir parçası olmalıdır. Hem çocukların açık hava ortamlarının zengin öğrenme olanaklarından yararlanabilmeleri hem de öğretmenlerin açık hava öğrenme ortamlarını zenginleştirebilecekleri seçeneklerin sunulabilmesi için program materyallerinde yer verilen etkinliklerin farklı etkinlik çeşitlerini içerecek ve çocuğun bütüncül gelişimini destekleyecek şekilde zenginleştirilmesi önerilmektedir. Ayrıca aile eğitimi kapsamında uygulanması önerilen etkinliklerin, açı havayı etkileşimli öğrenme alanı olarak ele alacak şekilde, çeşitlendirilmiş ve zenginleştirilmiş etkinlikler olarak yenilenmesine ihtiyaç olduğu açıktır.

Açık havada eğitimin önemine ilişkin en güzel vurgulardan biri "Hababam Sınıfı" adlı Yeşilçam klasiğinde göze çarpar. "Hababam Sınıfı Tatilde" adlı filmde kampta yemek yerken öğrenciler ile Mahmut Hoca arasında şöyle bir diyalog geçer;

Tulum Hayri: Ders okulda olur hocam.

Mahmut Hoca: Burası da okul çocuklar.

İnek Şaban: Böyle okul mu olurmuş, Mahmut Hoca?

Mahmut Hoca: Okul sadece dört yanı duvarla çevrili tepesinde dam olan yer değildir. Okul her yerdir. Sırasında bir orman, sırasında dağ başı... Öğrenimin, bilginin olduğu her yer okuldur.

Tulum Hayri: Allah aşkına hocam, bu okulda insan ne öğrenir?

Mahmut Hoca: Yaşamayı, mücadele etmeyi, doğayla savaşmayı öğrenirsiniz. Bilgili olmayı en önemlisi kendinize karşı

saygılı olmayı öğrenirsiniz. Bu saydıklarım eğer bir okulda yoksa orada sadece bir taş yığını vardır. (Ataman, Eğilmez ve Eğilmez, 1978).

Okulların bir taş yığınından ibaret olmaması, çocuklarımıza yaşamsal ihtiyacı olan "özgür" ortamı sunabilmesi dileğiyle...

\section{Yazar(lar)ın Beyanı}

Araştırmacıların katkı oranı beyanı: Araştırmanın tüm aşamaları yazar tarafından yapılmıştır.

Etik Kurul Kararı: Bu çalışma etik kurul kararı gerektirmemektedir.

Çatışma beyanı: Herhangi bir kişi, kurum ya da kuruluşla çıkar çatışması bulunmamaktadır.

Destek ve teşekkür: Araştırma için herhangi bir kurum ya da kuruluştan destek alınmamıştır.

\section{Kaynaklar}

Aktaş Arnas, Y. ve Sarıbaş, Ş. (2020). An investigation of pre-school children's and their parents' outdoor play experiences. Pegem Ĕ̆itim ve Öğretim Dergisi, 10(2), 373-398.

Alat, Z., Akgümüş, Ö. ve Cavalı, D. (2012). Okul öncesi eğitimde açık hava etkinliklerine yönelik öğretmen görüş ve uygulamaları. Mersin Üniversitesi Ĕ̆itim Fakültesi Dergisi, 8(3), 47-62.

Altman, I. ve Wohlwill, J. F. (1978). Children and environment. New York: Plenum Press.

Arabacı, N. ve Çıtak, Ş. (2017). Okul öncesi dönemdeki çocukların "oyun" ve "açık alan (bahçe)" etkinlikleri ile ilgili görüşlerinin incelenmesi ve örnek bir bahçe düzenleme çalışması. Akdeniz Eğitim Araştırmaları Dergisi, 11(21), 28-43.

Aral, N. ve Kadan, G. (2018). 2013 Okul öncesi eğitim programının değerler eğitimi bağlamında 
incelenmesi. Erken Çocukluk Çalışmaları Dergisi, 2(1), 113-131.

Ataman, N., Eğilmez, E. (Yapımcı) ve Eğilmez, E. (Yönetmen). (1978). Hababam sınıfı tatilde [Sinema filmi]. Türkiye: Arzu Film.

Babaroğlu, A. (2018). Eğitim ortamları açısından okul öncesi eğitim kurumları. Abant İzzet Baysal Üniversitesi Eğitim Fakültesi Dergisi, 18(3), 1313-1330.

Baki, A. ve Hacısalihoğlu-Karadeniz, M. (2013). Okul öncesi eğitim programının matematik uygulama sürecinden yansımalar. Kastamonu Üniversitesi Kastamonu Ĕ̆itim Dergisi, 21(2), 619-636.

Başaran, S. T. ve Ulubey, Ö. (2018). 2013 Okul Öncesi Eğitim Programının değerlendirilmesi. Ankara Üniversitesi Ĕ̆itim Bilimleri Fakültesi Dergisi, 51(2), 1-38.

Bilton, H. (2010). Outdoor learning in the early years management and innovation. New York: Taylor \& Francis.

Bixler, R. D., Carlisle, C. L., Hammltt, W. E. ve Floyd, M. F. (1994). Observed fears and discomforts among urban students on field trips to wildland areas. The Journal of Environmental Education, 26(1), 24-33.

Blanchard, P. B. ve Buchanan, T. K. (2011). Environmental stewardship in early childhood. Childhood Education, 87(4), 232-238.

Bohling, V., Saarela,C. ve Miller, D. (2010). This never would have happened indoors: Supporting preschoolage childrens learning in a nature explore classroom in Minnesota. 11.11.2019 tarihinde https://dimensionsfoundation.org/wp-content/uploads/2016/07/skillsforestlkmn_10.pdf adresinden erişildi.

Bredekamp, S. (2015). Erken çocukluk eğitiminde etkili uygulamalar (H. Z. İnan ve T. İnan, Çev.) Ankara: Nobel Yayıncilik.

Burdette, H. L., ve Whitaker, R. C. (2005a). A national study of neighborhood safety, outdoor play, television viewing, and obesity in preschool children. Pediatrics, 116(3), 657-662.

Burdette, H. L. ve Whitaker, R.C. (2005b). Resurrecting free play in young children: Looking beyond fitness and fatness to attention, affiliation, and affect. Archives of Pediatrics $\mathcal{E}$ Adolescent Medicine, 159(1), 46-50.

Cetken, H. S. ve Sevimli-Çelik, S. (2018). Okul öncesi öğretmenlerinin dış mekân oyunlarına karşı bakış açılarının incelenmesi. Kuramsal Eğitimbilim Dergisi, 11(2), 318-341.

Cevher-Kalburan, N. (2014). Okul öncesi dönem çocukların dış mekânda oyun fırsatları ve ebeveyn görüşleri. Sosyal Politika Çalışmaları Dergisi, 32(1), 113-135.

Civelek, P. ve Akamca, G. Ö. (2017). Açık alan etkinliklerinin okul öncesi dönemdeki çocukların bilimsel süreç becerilerine ait kazanımlarına etkisi. International Periodical for the Languages, Literature and History of Turkish or Turkic, 12(18), 173-194.

Clements, R. (2004). An investigation of the status of outdoor play. Contemporary Issues in Early Childhood, 5(1), 68-80

Cooper, A. (2015). Nature and the outdoor learning environment: The forgotten resource in early childhood education. International Journal of Early Childhood Environmental Education, 3(1), 85-97.

Çamlıbel-Çakmak, Ö. (2010). Okul öncesi eğitim kurumlarında aile katılımı. Abant İzzet Baysal Üniversitesi Sosyal Bilimler Enstitüsü Dergisi, 1(20), 1-17.

Çamlıbel-Çakmak, Ö. (2018, Nisan). Okul öncesi eğitimde kavramlar ile ilgili yapılan lisansüstü tezlerin incelenmesi. 1. Uluslararası Eğitim ve Sosyal Bilimlerde Yeni Ufuklar Kongresi Bildiriler Kitabı (s. 286 - 299) içinde. İstanbul. 11.10.2020 tarihinde https://dergipark.org.tr/en/download/article-file/466358 adresinden erişildi.

Çelik, A. (2012). Okul öncesi eğitim kurumlarında açık alan kullanımı: Kocaeli örneği. Atatürk Üniversitesi 
Ziraat Fakültesi Dergisi, 43(1), 79-88.

Çukur, D. (2011). Okul öncesi çocukluk döneminde sağlıklı gelişimi destekleyici dış mekân tasarımı. SDÜ Orman Fakültesi Dergisi, 12(1), 70-76.

Davies, M. M. (1996). Outdoors: An important context for young children's development. Early Child Development and Care, 115(1), 37-49.

Dowdell, K., Gray, T. ve Malone, K. (2011). Nature and its influence on children's outdoor play. Journal of Outdoor and Environmental Education, 15(2), 24-35.

Eğitimde Bilişim Ağı. (2018). 25.12.2018 tarihinde http://okuloncesi.eba.gov.tr/Haber/Detay/3 adresinden erişildi.

Erol, A. ve Gülay Ogelman, H. (2019). Çevre eğitimi aile katılım etkinliklerinin anne ve babaların çevreye yönelik tutumlarına etkisinin incelenmesi. İlköğretim Online, 18(2), 916-938.

Essa, E. L. (1992). Introduction to early childhood education. New York: Delmar.

Fjortoft, I. (2001). The natural environment as a playground for children: The impact of outdoor play activities in pre-primary school children. Early Childhood Education Journal, 29(2), 111-117.

Fjortoft, I. (2004). Landscape as playscape: The effects of natural environments on children's play and motor development. Children, Youth and Environments 14(2), 21-44.

Fjortoft, I. ve Sageie, J. (2000). The natural environment as a playground for children. Landscape and Urban Planning, 48(1-2), 83-97.

Frost, J. L. ve Wortham, S. (1988). The evolution of American playgrounds. Young Children, 43(5), 19-28.

Gardner, H. (2000). Intelligence reframed: Multiple intelligences for the 21st century. New York: Basic Books.

Göle, M. ve Temel, F. (2020). Okul Öncesi Eğitim Programı kalite değerlendirme ölçeği geçerlik ve güvenirlik çalışması. Uluslararası Erken Çocukluk Ë̆̈itimi Çalışmaları Dergisi, 5(2), 62-81.

Hart, C. H. ve Sheehan, R. (1986). Preschoolers' play behavior in outdoor environments: Effects of traditional and contemporary playgrounds. American Educational Research Journal, 23(4), 668.

Hearron, P. F. ve Hildebrant, V. (2013). Guiding young children. NJ: Pearson Education, Inc.

Herrington, S. ve Studtmann, K. (1998). Landscape interventions: New directions for the design of children's outdoor play environments. Landscape and Urban Planning, 42(1998), 191-205.

Hetherington, S. (2001). Kindergarten: Garden pedagogy from romanticism to reform. Landscape Journal, 20(10), 30-34

Jacobi-Vessels, J. L. (2013). Discovering nature: The benefits of teaching outside of the classroom. Dimensions of Early Childhood, 41(3), 4-10.

Kahriman-Pamuk, D. (2020). An exploration of parents' perceptions concerning the forest preschool. International Electronic Journal of Environmental Education, 10(2), 237-250.

Kahriman-Pamuk, D. ve Ahi, B. (2019). A phenomenological study on the school concept of the children attending the forest school. Ĕgitimde Nitel Arastirmalar Dergisi, 7(4), 1386-1407.

Kalburan, N. C. (2014). Denizli ilinde bulunan resmi ve özel anaokulu bahçelerinin karşılaştırmalı olarak incelenmesi. Pamukkale Üniversitesi Sosyal Bilimler Enstitüsü Dergisi, 18(3), 99-113.

Kanat, T. (2020). Orman okulu uygulamalarının okul öncesi dönem çocukları üzerindeki etkilerinin değerlendirilmesi (Yayınlanmamış yüksek lisans tezi). Çanakkale On Sekiz Mart Üniversitesi, Çanakkale.

Kandır, A. ve Türkoğlu, D. (2015). MEB 2013 Okul Öncesi Eğitim Programı'nın Müzikal Becerilerin Gelişimi Yönünden Değerlendirilmesi. Hacettepe University Faculty of Health Sciences Journal, 1(2), 339-350. 
Keçecioğlu, Ö. (2015). MEB Okul Öncesi Eğitim Programı ve Montessori yaklaşımına göre eğitim alan 5 yaş çocuklarının sosyal becerilerinin incelenmesi (Yayınlanmamış yüksek lisans tezi). Marmara Üniversitesi, İstanbul.

Kellert, S. R. (2005). Building for life: Designing and understanding the human-nature connection. Washington, DC: Island Press.

Kelley, S. S. ve Williams, D. R. (2013). Teacher professional learning communities for sustainability: Supporting STEM in learning gardens in low-income schools. Journal of Sustainability Education, 5(1), 327345.

Khan, M. (2012). Outdoor as learning environment for children at a primary school of Bangladesh (Yayımlanmamış yüksek lisans tezi). Bangladesh University, Dhaka.

Kızıltepe, Z. (2017). İçerik analizi. F. N. Seggie ve Y. Bayyurt (Ed.), Nitel araştırma yöntem, teknik, analiz ve yaklaşımları (s. 253-266) içinde. Ankara: Anı Yayıncılık.

Kiewra, C. ve Veselack, E. (2016). Playing with natura: Supporting preschoolers' creativity in natural outdoor classrooms. The International Journal of Early Childhood Environmental Education, 4(1), 70-95.

Kostelnik, M. J., Soderman, A. K., Whiren, A. P. ve Rupiper, M. L. (2019). Gelişime uygun eğitim programı: Erken çocukluk eğitiminde en iyi uygulamalar (E. Ahmetoğlu ve İ. H. Acar, Çev.). Ankara: Nobel Yayıncllık.

Koyuncu, M. (2019). Okul öncesi eğitimde alternatif yaklaşım: Orman okullarında öğretmen, veli ve yönetici görüşlerinin incelenmesi (Yayınlanmamış yüksek lisans tezi). Ankara Yıldırım Beyazıt Üniversitesi, Ankara.

Krippendorff, K. (2004). Content analysis: An introduction to its methodology (2. bs.). California: Sage.

Laevers, F. (2000). Forward to the basics! Deep level learning and the experiential approach. Early Years, 20(2), 20-29.

Louv, R. (2010). Doğadaki son çocuk çocuklarımızdaki doğa yoksunluğu ve doğanın sağaltıcı gücü (C. Temürcü, Çev.). Ankara: TÜBİTAK Popüler Bilim Kitapları.

Maynard, T. ve Waters, J. (2007). Learning in the outdoor environment: A missed opportunity? Early Years, $27(3), 255-265$.

McClintic, S. ve Petty, K. (2015) Exploring early childhood teachers' beliefs and practices about preschool outdoor play: A qualitative study. Journal of Early Childhood Teacher Education, 36(1), 24-43.

Milli Eğitim Bakanlığı. (2013a). Okul öncesi eğitim programı 29.12.2018 tarihinde http://tegm.meb.gov.tr/dosya/okuloncesi/ooproram.pdf adresinden erişildi.

Milli Eğitim Bakanlığı. (2013b). Etkinlik kitabı. 29.12.2018 tarihinde http://anaokulu.cu.edu.tr/_file/OOEP_2013_Etkinlik_Kitabi.pdf adresinden erişildi.

Milli Eğitim Bakanlığı. (2013c). Okul öncesi eğitim programı ile bütünleştirilmiş aile destek eğitim rehberi (OBADER). 29.12.2018 tarihinde http://anaokulu.cu.edu.tr/_/file/OBADER_2013.pdf adresinden erişildi.

Milli Eğitim Bakanlığı. (2018). Öğretmenler için etkinlik kitabı. İzmir: MEB Devlet Kitapları.

Millward, A. ve Whey, R. (1997). Facilitating play on housing estates. London: Chartered Institute of Housing and Joseph Rowntree Foundation.

National Association for Sport and Physical Education. (2005). Physical education for lifelong fitness (2. bs.). Champaign, IL: Human Kinetics.

Olsen, H. ve Smith, B. (2017). Sandboxes, loose parts, and playground equipment: A descriptive exploration of outdoor play environments. Early Child Development and Care, 187(5-6), 1055-1068.

Orçan Kaçan, M., Halmatov, M. ve Kartaltepe, O. (2017). Okul öncesi eğitim kurumları bahçelerinin incelenmesi. Erken Çocukluk Çalışmaları Dergisi, 1(1), 60-70. 
Özsırkıntı, D., Akay, C. ve Yılmaz Bolat, E. (2014). Okul öncesi öğretmenlerinin okul öncesi eğitim programı hakkındaki görüşleri (Adana ili örneği). Ahi Evran Üniversitesi Kırşehir Eğitim Fakültesi Dergisi, 15(1), 313331.

Payne, P. G. (2010). Moral spaces, the struggle for an intergenerational environmental thesis and the social ecology of families: An 'other' form of environmental education. Environmental Education Research, 16(2), 209-231.

Perry, J. P. (2001). Outdoor play: Teaching strategies with young children. NY: Teachers College Press.

Quigley, C., Pongsanon, K. ve Akerson, V. L. (2011). If we teach them, they can learn: Young students views of nature of science during an informal science education program. Journal of Science Teacher Education, 22(2), 129-149.

Rivkin, M. (1998). "Happy play in grassy places": The importance of the outdoor environment in Dewey's educational ideal. Early Childhood Education Journal, 25(3), 199-202.

Schultz, P. W., Shriver, C., Tabanico, J. J. ve Khazian, A. M. (2004). Implicit connections with nature. Journal of Environmental Psychology, 24(1), 31-42.

Shim, S.-Y., Herwig, J. E. ve Shelley, M. (2001). Preschoolers' play behaviors with peers in classroom and playground settings. Journal of Research in Childhood Education, 15(2), 149-163.

Staempfli, M. B. (2009). Reintroducing adventure into children's outdoor play environments. Environment and Behavior, 41(2), 268-280.

Sunar, D. ve Fişek, G. O. (2005). Contemporary Turkish families. J. L. Roopnarine ve U. P. Gielen (Ed.), Families in global perspective (s. 169-183) içinde. Boston: Pearson.

Talay, İ., Aslan, F. ve Belkayalı, N. (2010). Okul öncesi eğitim kurumlarında doğa dostu ve çocuk katılımı temelli dış mekân tasarım yaklaşımları bir proje önerisi. Kastamonu Ĕ̆itim Dergisi, 18(1), 317-322.

Tepedağ, D. ve Aktaş Arnas, Y. (2017). Okul öncesi öğretmenlerinin okul bahçesini eğitsel amaçlı kullanımına yönelik görüşlerinin incelenmesi. Uluslararası Erken Çocukluk Eğitimi Çalışmaları Dergisi, 2(2), 50-67.

Tezel Şahin, F. ve Cevher Kalburan, F. N. (2009). Aile eğitim programları ve etkililiği: Dünyada neler uygulaniyor? Pamukkale Üniversitesi Ĕ̆itim Fakültesi Dergisi, 1(25), 1-12.

Towell, J. L. (2005). Quality outdoor preschool environments in early care and education centers (Yayımlanmamış yüksek lisans tezi). Oklahoma State University, Stillwater, OK.

Tucker, P. (2008). The physical activity levels of preschool-aged children: A systematic review. Early Childhood Research Quarterly, 23(4), 547-558.

Tuğluk, M. N. ve Özkan, B. (2019). MEB 2013 Okul Öncesi Eğitim Programının 21. yüzyıl becerileri açısından analizi. Temel Ĕ̆gitim Dergisi, 1(4), 29-38.

Tükel, A. (2017). 2013 Okul Öncesi Eğitim Programı ile ilgili öğretmen görüşlerinin değerlendirilmesi (Yayımlanmamış yüksek lisans tezi). Selçuk Üniversitesi, Konya.

Ulutaş, B. (2017). Doküman analizi. F. N. Seggie ve Y. Bayyurt (Ed.), Nitel araştırma yöntem, teknik, analiz ve yaklaşımları (s. 279-297) içinde. Ankara: Anı Yayıncılık.

Valentine, G. ve McKendrick, J. (1997). Children's outdoor play: Exploring parental concerns about children's safety and the changing nature of childhood. Geoforum, 28(2), 219-235.

Waite, S. (2010). Losing our way? The downward path for outdoor learning for children aged 2-11 years. Journal of Adventure Education and Outdoor Learning, 10(2), 111-126.

Wells, N. M. (2000). At home with nature effects of "greenness" on children's cognitive functioning. Environment and Behavior, 32(6), 775-795. 
White, J. (2008). Playing and learning outdoors: making provision for high-quality experiences in the outdoor environment. New York: Routledge.

White, R. (2004). Children's relationship with nature: Its importance to children's development and the earth's future. 27.12.2019 tarihinde http://www.childrennatureandyou.org/Young\%20Children's\%20Relationship\%20with\%20Nature\%20White.pdf adresinden erişildi.

Wilson, E. O. (2003). Biophilia. London: Harward University Press.

Wilson, R. (2008). Nature and young children: Encouraging creative play and learning in natural environments. New York: Routledge.

Woolley, H. ve Lowe, A. (2013). Exploring the relationship between design approach and play value of outdoor play spaces. Landscape Research, 38(1), 53-74.

Yıldırım, A. ve Şimşek, H. (2011). Sosyal bilimlerde nitel araştırma yöntemleri. Ankara: Seçkin Yayıncılık. 


\section{EXTENDED ABSTRACT}

\section{Introduction}

An increase in the importance attributed to outdoor education in the Turkish national education curriculum, may result in the development of supportive policies. For these reasons, it is useful to examine the educational curricula and activity books, which are the expressions of the principles, objectives and practices of our national education policy in order to determine the current situation and take necessary precautions. In this regard, the aim of this study is to examine the outdoor activities in the Family Support Education Guide (OBADER), Activity Book (AB) and Activity Book for Teachers (ABfT), which constitute the materials of the Ministry of National Education (MoNE) Preschool Education Curriculum (PsC), in terms of variables such as activity type, development area, subject, concept, and the positioning of outdoor activities. The following questions were adopted in line with this aim:

1. Considering the activities recommended to be performed outdoors in $A B$ and ABfT, what is the distribution of activities in terms of:
a. activity type,
b. area of development,
c. subject discussed,
d. concept discussed,
e. and the positioning of outdoors activities?

2. What are the quantitative differences between the $\mathrm{AB}$ and $\mathrm{ABfT}$, which reflect the implementation of the MoNE PsC, in terms of the activities recommended to be performed outdoors?

3. Is there an emphasis on the importance of outdoor education in OBADER?

\section{Method}

Within the scope of this study, the AB, OBADER and ABfT application materials were examined as factual evidence and analyzed using a document analysis method. Thus, it was determined that one out of 62 activities in OBADER, five out of 40 activities in $\mathrm{AB}$ and 27 out of 340 activities in ABfT were outdoor activities. Considering the process of analyzing and interpreting the identified activities, the following stages were followed: coding, category development, frequency calculation and interpretation.

\section{Results}

When the distribution of the activities recommended to be performed outdoors in the $A B$ and ABfT was examined in terms of activity type, it was seen that the most frequent outdoor activity type was art $(3 / 5$ and $14 / 27)$, and the rarest outdoor activity type was preparation for reading and writing ( 0 and 1/27) and music $(1 / 5$ and 0$)$. When the distribution of the activities recommended to be performed outdoors in the $A B$ and ABfT was examined in terms of area of development, it was seen that the most frequent supported area of development was motor development (4/5), and was cognitive (14/27). When the distribution of the activities recommended to be performed outdoors in the $\mathrm{AB}$ and $\mathrm{ABfT}$ was examined in terms of subject, it was seen that the most frequently recommended subject areas were "the living creatures-life" (1/5 and 6/27) and "dynamic play" (1/5 and 6/27). The subject area of "senses" ( 0 and 2/27) was the least recommended subject area. When the distribution of the activities recommended to be performed outdoors in the AB and ABfT was examined in terms of concept, it was seen that ABfT included seven concepts, and AB included three concepts. When the distribution of the activities recommended to be performed outdoors in the AB and ABfT was examined in terms of the positioning of the outdoors, it was seen that both books positioned the outdoors as an interactive learning environment.

When the books were compared with each other in terms of quantitative differences in activities recommended to be performed outdoors, it was seen that 5 (12.5\%) activities out of 40 in $\mathrm{AB}$ and $27(7.9 \%)$ 
activities out of 340 in ABfT were outdoor activities.

OBADER was evaluated in terms of whether it included an emphasis on the importance of outdoors education. In line with the investigation, the expression "Families can keep a close eye on their children during field trips and outdoor activities..." (MEB, 2013c, p. 23) was found to be remarkable.

\section{Conclusion}

When the distribution of suggestions for outdoor activities according to types of activities was examined in the activity books, it was seen that they included the most art activities and the least preparation for literacy and music activities. As Davies (1996) states, outdoor experiences may include activities such as art, music, or storytelling, often thought to be unique to the indoors.

When the distribution of the activities was examined according to their development areas, it was seen that motor development was most supported in $\mathrm{AB}$, and cognitive development was most supported in ABfT. Outdoor play contributes to the child's development (Wilson, 2008) in terms of emotional and social development (Millward and Whey, 1997), complex language and speaking skills (Bohling, Saarela, and Miller, 2010).

When the activities were examined according to their subjects, it was seen that the most common subject area was "living creatures-life" and "dynamic play". Children who know and value the living creatures in their environment may be more likely to find ways to protect the environment (Blanchard \& Buchanan, 2011).

When the activities were evaluated according to the concept group, it was seen that "opposite concepts" were often addressed, but "geometric figures" were rarely dealt with, and the concept of "senses" was included at a limited level. However, in outdoor activities, children have rich sensory experiences through their interaction with objects and living creatures of different odors, textures, sounds, colors or tastes (Davies, 1996).

In the activity books, when we examined the way the outdoors were positioned, it was seen that the most common positioning was the "interactive learning domain", and the least common positioning was "a place which is visited for a short period of time". The positioning of the outdoors as an interactive learning environment in the activity books can be considered an improvement that can create positive changes.

When the curriculum materials were compared regarding the inclusion of outdoor activities, it was seen that one of 62 activities in OBADER, five of 40 activities in AB, and 27 of 340 activities in ABfT were outdoor activities. The proportional decrease observed between the two activity books was an indication that the highlighted importance of outdoor activities in the curriculum and literature could not be reflected in practice. 